\title{
Impact of the environment upon the Candida albicans cell wall and immune evasion
}

Delma S. Childers $\$$, Gabriela M. Avelar ${ }^{\$}$, Judith M. Bain $\$$, Daniel E. Larcombe, Arnab Pradhan, Susan Budge, Helen Heaney and Alistair J.P. Brown*

Medical Research Council Centre for Medical Mycology at the University of Aberdeen, Institute of Medical Sciences, Foresterhill, Aberdeen AB25 2ZD, UK.

\$ These authors contributed equally to this work.

* Communicating Author:

Alistair J P Brown

E: al.brown@abdn.ac.uk

T: +44 (0)1224 437482

Running title: Cell wall adaptation and immune evasion

Key words: Candida albicans; cell wall structure; cell wall adaptation; cell wall signalling; immune evasion; host-fungus interactions 


\section{Abstract}

The fungal cell wall is an essential organelle that maintains cellular morphology and protects the fungus from environmental insults. For fungal pathogens such as Candida albicans, it provides a degree of protection against attack by host immune defences. However, the cell wall also presents key epitopes that trigger host immunity, and attractive targets for antifungal drugs. Rather than being a rigid shield, it has become clear that the fungal cell wall is an elastic organelle that permits rapid changes in cell volume and the transit of large liposomal particles such as extracellular vesicles. The fungal cell wall is also flexible in that it adapts to local environmental inputs, thereby enhancing the fitness of the fungus in these microenvironments. Recent evidence indicates that this cell wall adaptation affects hostfungus interactions by altering the exposure of major cell wall epitopes that are recognised by innate immune cells. Therefore, we discuss the impact of environmental adaptation upon fungal cell wall structure and immune evasion, focussing on $C$. albicans and drawing parallels with other fungal pathogens.

\section{Introduction}

The ascomycete fungus, Candida albicans, is carried as a relatively harmless commensal by most healthy individuals in their oral cavity, or urogenital and gastrointestinal tracts. In general, the local epithelial barriers, innate immune defences and microbiota limit the colonisation and outgrowth by $C$. albicans cells. However, the perturbation of any of these local defences often leads to local mucosal infection (thrush) $(1,2)$. Most women suffer at least one episode of vaginitis in their lifetime, and oral thrush is common in babies, the elderly, diabetics, and HIV patients. C. albicans is the most common cause of fungal mucosal infections (3). In neutropenic patients, whose immune defences are severely compromised, C. albicans can cause systemic infections of the blood and internal organs $(4,5)$. Despite the availability of several classes of antifungal drug, including azoles, polyenes, echinocandins, and flucytosine (6), these systemic infections display about $40 \%$ mortality $(7,8)$. This, combined with the emergence of resistance to the current antifungal drugs in clinical use, means that there is a clear need for the development of new, more effective antifungals (7).

From a clinical perspective, the fungal cell wall represents an attractive target for the development of new antifungal drugs $(6,9)$. This is because human cells lack a cell wall, whereas the cell wall is essential for the viability of fungal pathogens such as C. albicans (1012). Therefore, drugs that target cell wall biosynthesis or function are less likely to perturb human cells. The $C$. albicans cell wall also represents the first point of direct contact with the host, and cell wall molecules are exploited as key recognition targets by our immune defences. For this reason, the cell wall is also an attractive target for the development of vaccines and immunotherapeutics that might prevent or combat Candida infections. In addition, structural distinctions between the cell walls of pathogenic fungal species (13) represent a point of leverage for the development of the novel diagnostics that are required to accelerate the diagnosis, and thereby improve the prognoses of life-threatening systemic infections (7). Therefore, a comprehensive understanding of the structure and function of the fungal cell wall is vital for the elaboration of the new antifungal drugs, immunotherapies, diagnostics, and vaccines that ultimately will improve patient outcomes.

From the perspective of the fungus, the cell wall is a vital organelle that requires significant metabolic and energetic investment to construct. (The wall comprises about $30 \%$ of the dry weight of a yeast cell (14). The cell wall provides protection against environmental insults (9). It maintains cell shape and osmotic integrity, asserting the cellular morphology 
driven by the regulatory apparatus that establishes the balance between isotropic and polarised growth, generating morphogenetic transitions between yeast, pseudohyphal and hyphal growth forms in response to the environmental conditions (15). Yet the cell wall is an elastic, not a rigid structure, which permits the transit of large liposomes and extracellular vesicles $(16,17)$, as well as rapid changes in cell volume in response to osmotic challenges (18). Furthermore, rather than being a relatively inert shield, the cell wall responds to local inputs as the fungus adapts to environmental change (19-21). Therefore the fungal cell wall is a remarkable organelle that is simultaneously robust but elastic, and stable but flexible.

In this article we focus on the cell wall of the major pathogen, C. albicans. We review the structure of the $C$. albicans cell wall, its stability and elasticity; how the cell wall responds to environmental challenges, whether natural or therapeutic; and how changes in the C. albicans cell wall affect host-fungus interactions. We then discuss parallels with other fungal pathogens before suggesting key questions for the future.

\section{Structure and synthesis of the $C$. albicans cell wall}

Significant differences exist between the cell walls of the major fungal pathogens of humans $(9,13)$. Nevertheless, some of the macromolecular building blocks that comprise the cell wall are conserved across most of these fungal species. These consist of $\beta-1,3-$ and $\beta-$ 1,6-glucan, chitin and mannoproteins. Additionally, some fungal cell walls contain melanin, chitosan and $\beta-1,4$-glucan $(9,22-24)$. A combination of microscopy, biochemistry and molecular genetics has shown clearly that the $C$. albicans cell wall comprises two main layers: an inner layer of chitin and glucan cross-linked together, and an outer layer of mannan fibrils that are covalently attached to this inner layer via their anchoring mannoproteins (Figure 1).

Chitin is a linear homopolymer of $\beta-1,4$-linked $N$-acetylglucosamine, which forms antiparallel chains linked by intra-chain hydrogen bonds. Chitin accounts for only about $2-3 \%$ of the dry weight of the $C$. albicans yeast cell wall. Yet it is a strong fibrous structural component of the inner layer that contributes significantly to the overall integrity of the cell wall. C. albicans mutants with impaired chitin synthesis present with a disordered cell wall architecture and display osmotic instability $(25,26)$. In $C$. albicans, a small fraction of chitin (less than $5 \%$ ) is deacetylated to chitosan by one or more chitin deacetylases, making chitin fibrils more elastic and protecting them from the action of hostile chitinases (26).

In C. albicans chitin is synthesized by a family of four chitin synthases, representing three different classes of chitin synthase that generate chitin microfibrils of different lengths (25). Together, these enzymes engineer the chitin skeleton in the fungal cell wall and septum. Chs 1 is an essential Class II enzyme that is required for the synthesis of the primary septum. Chs 3 is a Class IV enzyme, which is usually located in the tip of buds and hyphal cells and synthesizes the majority of chitin found in the fungal cell wall and septum. Chs2 and Chs8 also contribute to cell wall integrity during normal growth and stress conditions. These Class I enzymes account for most of the chitin synthase activity that is measurable in vitro, and indeed the deletion of CHS2 alone reduces in vitro chitin synthase activity by $80-91 \%(11,26-28)$.

$\beta$-Glucan is the major structural polysaccharide of the $C$. albicans cell wall, accounting for $50-60 \%$ of the dry weight of the yeast cell wall $(22,23)$. $\beta$-Glucan is composed of chains of glucose residues linked via $\beta-1,3-$ or $\beta-1,6$ linkages. $\beta-1,3-$ Glucan fibrils represent the main structural component of the $C$. albicans cell wall, and chitin, $\beta-1,6-$ glucan and mannoproteins are covalently attached to this $\beta-1,3-$ glucan network in the inner layer of the wall. $\beta-1,3-$ Glucan is synthesized at the plasma membrane and extruded into extracellular space by the beta-1,3glucan synthase complex, which consists of catalytic subunits encoded by GSC1/FKS1 and 
GSC2/FKS2, and a small regulatory GTPase encoded by $R H O 1$ (29,30). $\beta-1,3-G l u c a n$ synthase is essential for fungal viability and is the target of echinocandin drugs, such as caspofungin (10).

$\beta-1,6$-Glucan is less abundant than $\beta-1,3$-glucan. Branched $\beta-1,6$-glucan structures are crosslinked to $\beta-1,3$-glucan in the inner layer of the $C$. albicans cell wall, providing an additional platform for the covalent anchoring of some cell wall mannoproteins (31). A number of genes are involved in $\beta-1,6-$ glucan biosynthesis, including KRE5, KRE6, KRE9, BIG1 and SKN1. Although it is not clear where $\beta-1,6$-glucan synthesis occurs, it does involve enzymes localised in the endoplasmic reticulum and the Golgi apparatus (32).

The mannoproteins in the $C$. albicans cell wall are frequently heavily decorated with $N$ and/or O-linked oligosaccharides $(23,33)$. Together with phospholipomannans, these represent up to $30-40 \%$ of the dry weight of the cell wall. The O-mannans are relatively short linear carbohydrate polymers comprised of two to six a-1,2-linked mannose units. Their synthesis requires the activities of PMR1, the PMT gene family, MNT1, and MNT2 (34-37). The addition of the first mannose residue to the polypeptide chain is catalysed by $O$ mannosyltransferases (encoded by PMT genes), whilst Mnt1 and Mnt2 are responsible for the addition of the first and second $\alpha-1,2$-mannose units into the $\alpha$-mannose backbone. The resultant $O$-linked oligosaccharides are thought to promote a rod-like conformation to the serine-threonine-rich repeats to which they are generally attached (38).

The outer layer of the $C$. albicans cell wall is composed of highly branched $N$-linked oligosaccharide structures that are covalently linked to asparagine residues in the mannoproteins. These $\mathrm{N}$-mannans contain a $\mathrm{N}$-glycan core, to which are attached long branched chains with an $\alpha-1,6$-mannose backbone and side chains of oligomannosides linked via $\alpha-1,2$ or $\alpha-1,3$ bonds (23). The synthesis of the $N$-linked oligosaccharide core structure occurs in the endoplasmic reticulum and involves the sequential addition of sugar residues by glycosyltransferases, encoded by asparagine-linked glycosylation ( $A L G)$ genes. The mannosyltransferase Och1 catalyses the addition of the first alpha-1,6-mannose (39) and the branched oligosaccharide structure is then added to the nascent protein by the oligosaccharyltransferase complex. After the initial glycosylation, the mannoprotein is further modified in the ER and Golgi apparatus. Golgi resident enzymes, encoded by members of the $K T R / K R E / M N T$ and $M N N$ gene families, process and elongate the $N$-linked as well as $O-$ linked oligosaccharides (40-42). Phosphomannan is a $\beta-1,2$-mannose moiety linked to the branched $N$-glycan via a phosphodiester bond. A similar moiety can be linked to lipid domains creating the phospholipomannans. Different enzymes from the $M N N$ and BMT families participate in the synthesis of phosphomannan and phospholipomannans (42-44).

There are two main classes of cell wall mannoprotein in $C$. albicans based on the nature of their linkage to cell wall polymers. GPI-anchored proteins, which are the most abundant class of cell wall mannoprotein, are covalently attached via their carboxy-terminal glycosylphosphatidylinositol (GPI) anchor to $\beta-1,6$-glucan which, in turn, is linked to $\beta-1,3-$ glucan (31). Pir proteins (proteins with internal repeats) are less abundant, and these are covalently linked directly to $\beta-1,3$-glucan $(31,45)$.

Cell wall proteins provide anchors for the mannan outer layer of the cell wall. They contribute to the structural integrity of the cell wall, and some are cell wall remodelling enzymes responsible for generating essential covalent linkages between cell wall components $(18,46,47)$. Transglycosylases from the GH72 family catalyse glucan remodelling, and their inactivation affects growth, morphology and virulence. For example, PHR1 and PHR2 (pHresponsive genes 1 and 2 ) encode members of this family, and they catalyse the $\mathrm{pH}$-regulated cross-links between $\beta-1,6$ - and $\beta-1,3-$ glucans. PHR1 plays a crucial role in the formation of 
the hyphal cell wall and in pathogenesis $(47,48)$. The GPI-anchored yapsin-like aspartic proteases Sap9 and Sap10 have functions in cell surface integrity and cell separation during budding, while the $C R H$ family of chitin-glucanosyltransferases (Crh11, Crh12, Utr2) are involved in formation of linkages between $\beta-1,3$-glucan and chitin (46). The degree of crosslinking between components of the cell wall is important for its organization and integrity, as this determines its elasticity, resistance and porosity. This is evidenced by the deletion or overexpression of genes encoding cell wall remodelling enzymes, which results in altered sensitivity to cell wall disrupting agents, such as Congo Red, Calcofluor White, SDS, and high $\mathrm{Ca}^{2+}$ concentrations $(18,46,47)$.

Besides its structural role, the cell wall promotes $C$. albicans pathogenicity, for example through adhesion, invasion and damage. Adhesins are important not only for fungal colonisation, but also for biofilm formation and interactions with other microbes. Most of the known adhesins are GPI anchored proteins, and many are members of multigene families such as the ALS and HWP gene families $(49,50)$. Some adhesion genes, such as ALS3 and HWP1, are expressed during hypha formation, which is why this morphotype is particularly adherent. The HWP adhesin family is required for adhesion to host cell proteins, biofilm formation, cell-cell aggregation and mating (49,51). HWP1, HWP2, and RBT1 expression is induced not only during hypha formation but also during mating of opaque cells. Another member of this family, EAP1, is expressed in both yeast and hyphal cells and is differentially regulated during yeast phenotypic switching $(51,52)$. Als 3 acts both as an adhesin and an invasin as it binds to a host receptor on epithelial or endothelial cells to induce endocytosis (53). Als3 also enables iron acquisition by binding transferrin and has effects on host cell damage and cytokine induction (54).

The general structure of the $C$. albicans cell wall has been reasonably well understood for some time $(9,22,23)$. However, recent technological advances are extending our knowledge of this field. For example, atomic force microscopy is providing direct information about cell wall structure and elasticity (55). Also, super-resolution microscopy has shown that phosphomannans, which are negatively charged, are critical for glucan masking at the cell surface (56). Furthermore, high resolution electron tomography has permitted the development of the first scale model of $C$. albicans cell wall architecture (Megan Lenardon and Neil Gow, personal communication). This deeper understanding of $C$. albicans cell wall biosynthesis, structure and organisation is helping the development of new therapies and diagnostics.

In the past, the fungal cell wall was often portrayed as a rigid shield-like structure in which, for example, chitin was compared to the steel in reinforced concrete. However, it has become clear that the cell wall is actually a surprisingly elastic structure. C. albicans releases extracellular vesicles which carry diverse cargo (including enzymes, toxins and nucleic acids, for example) that are believed to function in cell-to-cell communication, metabolism, and pathogenesis $(16,57,58)$. These extracellular vesicles vary in size from 50 to $850 \mathrm{~nm}$, and yet these membrane-bound compartments are able to transit through the cell wall into the surrounding milieu (16). Another study has demonstrated that large liposomal particles can gain entry to the cell by traversing the $C$. albicans cell wall. Transmission electron microscopy has revealed that Ambisome particles of 60 to $80 \mathrm{~nm}$, which are much larger than the predicted pore size of the cell wall (approximately $6 \mathrm{~nm}$ ), are able to transit through the cell wall whilst both particle and cell wall retain their integrity (17). The remarkable elasticity of the $C$. albicans cell wall is further reflected in the ability of $C$. albicans cells to undergo rapid and dramatic changes in volume in response to acute hyper-osmotic stress (18). Therefore, the crosslinked polymers of the $C$. albicans cell wall have evolved to provide an elastic and flexible structure, not a rigid shield. 


\section{Cell wall remodelling in response to damage}

The $C$. albicans cell wall is a dynamic structure that changes in response to morphogenetic triggers, other environmental inputs, genetic perturbation, and antifungal treatment. Transcriptomic, proteomic and biochemical studies from a number of research groups have revealed condition-specific programmes of cell wall protein expression (33) and carbohydrate content or synthesis (21). A complex network of signalling pathways regulates this cell wall adaptation. These pathways include the cell wall integrity pathway, high osmolarity glycerol (Hog1) mitogen activated protein kinase (MAPK) signalling, the calcineurin-calmodulin pathway, the protein kinase A (PKA) pathway, the Cek1 MAPK pathway, mitochondrial reactive oxygen species (ROS) signalling, casein kinase I (Yck2, Yck3), and the heat shock transcription factor (Hsf1)-Hsp90 auto-regulatory circuit (59-64) (Figure 2). This complexity probably reflects the absolute requirement to retain cell wall homeostasis in the face of a diverse range of environmental inputs and challenges.

This complex regulatory network presents an issue for antifungal therapy because, following exposure to an agent that compromises cell wall integrity, the network provides mechanisms for compensatory changes to the fungal cell wall. The major classes of antifungal drug impose major insults on the cell wall by targeting the synthesis or structural integrity of the cell wall and plasma membrane. Echinocandins, such as Caspofungin, target $\beta$-glucan biosynthesis via the catalytic subunit of glucan synthase, Fks1. The inhibition of Fks1, and hence $\beta$-glucan synthesis, by Caspofungin induces compensatory activities in the form of increased chitin synthesis and deposition in the cell wall (65). This elevation in cell wall chitin then protects cells against further Caspofungin treatment both in vitro and in vivo, thereby compromising the efficacy of the antifungal drug (66).

Azole drugs, such as fluconazole, target lanosterol 14-a-demethylase (Erg11) on the ergosterol biosynthesis pathway. This induces significant changes in plasma membrane rigidity and integrity. Although azoles do not appear to affect the cell wall directly, proteomics and cell wall sensitivity assays have shown that fluconazole treatment indirectly perturbs the integrity of the cell wall (67).

Clearly, genetic perturbation of cell wall components can significantly affect cell wall architecture. The loss of $\beta$-glucan synthase (Fks1) is lethal to $C$. albicans $(10,29)$. However, only one of the four chitin synthase genes (CHS1) is essential for viability $(12,68)$, due to compensatory changes in chitin synthesis rescuing the loss of other CHS genes (25). In general, cell wall mannoproteins themselves are rarely essential for viability, but the inactivation of some specific GPI-anchored proteins can perturb integrity of the $C$. albicans cell wall $(69,70)$. Mutations with more general effects upon the localisation or mannosylation of GPI anchored cell wall proteins also affect the sensitivity of $C$. albicans to cell wall stresses $(34-36,39,71,72)$. This type of approach, involving the analysis of cellular responses to the disruption of cell wall genes or to cell wall perturbing agents, has helped to elucidate the roles of specific proteins or protein families in virulence-related phenotypes, such as adhesion and biofilm formation. In the context of this article, it has also highlighted key mechanisms underlying cell wall maintenance and homeostasis.

The cell wall integrity signalling pathway drives the main compensatory changes in the cell wall that are initiated in response to antifungal drugs, other cell wall stresses, and genetic insults. This pathway has been evolutionarily conserved across those fungi investigated, and has been extensively studied in the model yeast, Saccharomyces cerevisiae. The cell wall integrity pathway responds to the activation of cell wall stress sensors by up-regulating the 
expression of cell wall synthesis genes via a highly conserved MAPK signalling cascade (Figure 2). In S. cerevisiae, signalling via the cell wall integrity pathway is initiated by the membrane proteins Wsc1, Wsc2, Wsc3, Mid2, and Mtl1, which act as cell integrity sensors (73). Upon loss of cell wall integrity, these sensors interact with Rom2 to activate Rho1, which then activates protein kinase $\mathrm{C}(\mathrm{Pkc} 1)$. Pkc1 signals to a MAPK module comprising Bck1, which activates MKK1/2, which phosphorylate and activate the MAPK, SIt2. SIt2 then activates the transcription factors RIm1 and Swi4/6, which induce the expression of genes that include the cell wall synthesis machinery (73).

C. albicans has homologs for many components of the cell wall integrity pathway (7476). Mutations in many affect the virulence of $C$. albicans, as well as its cell wall integrity, which suggests a key role for the cell wall integrity pathway in host niches. Furthermore, some components of this PKC-MAPK module in $C$. albicans have broader roles than their homologs in S. cerevisiae. For example, Mkc1, the $C$. albicans homolog of the S. cerevisiae MAPK SIt2, has an expanded role in regulating cellular morphogenesis under certain conditions (75). In addition, in C. albicans, Cas5 (rather than RIm1) appears to be the transcription factor that plays the major role in controlling key gene outputs of the cell wall integrity pathway (77). The cell wall integrity pathway also engages in cross talk with other important signalling pathways that include the cAMP-PKA, target of rapamycin (TOR), and Hog1 pathways, which helps to coordinate the response to specific stressors $(78,79)$ (Figure 2 ). It is worth noting that the cell wall integrity pathway also regulates important virulence traits in other fungi, for example capsule synthesis in Cryptococcus neoformans (80) and drug resistance and virulence in Aspergillus fumigatus (81).

\section{Cell wall remodelling in response to environmental change}

The ability of the C. albicans cell wall to remodel itself in response to sub-lethal concentrations of cell wall damaging agents (above) reflects the fact that cell wall remodelling is simply an important component of the normal adaptive responses of this fungus to environmental change. Yeast-hypha morphogenesis is one of the most studied adaptive responses of $C$. albicans because of the importance of this reversible morphological transition for host-fungus interactions and virulence (82-84). A range of environmental stimuli trigger hyphal development, including temperatures above $36^{\circ} \mathrm{C}$, neutral $\mathrm{pH}$, serum, bacterial peptidoglycan, high $\mathrm{CO}_{2}$ levels, release from quorum sensing and nutrient starvation. The resultant yeast-to-hypha transition is accompanied by shifts in the carbohydrate and proteomic content of the cell wall $(27,85-87)$. The cell walls of $C$. albicans hyphae can have up to twofold less mannan, three-fold more glucan, and five times more chitin than the walls of yeast cells (27). Furthermore, changes in glucan structure are associated with hypha formation (88). These changes in cell wall structure attenuate Dectin-1 mediated recognition of hyphae by innate immune cells, which compounds the physical challenges associated with the phagocytosis of mycelia (88-91).

Carbon source availability differs significantly between host niches. For example, glucose concentrations are about $0.06-0.1 \%$ in the bloodstream, but are essentially zero in the colon (92), whilst significant amounts of short chain fatty acids, such as lactate, are present in the vagina and colon $(93,94)$. Changes in carbon source have been found to exert major effects on the architecture and content of the $C$. albicans cell wall. Although the relative amounts of chitin, glucan and mannan remain similar, $C$. albicans cells grown on lactate, rather than glucose, have a thinner and less elastic cell wall $(18,20)$. These changes in cell wall architecture correlate with changes in the cell wall proteome and secretome. In particular, 
the levels of certain chitinases increase (Cht1, Cht3), as do the cell wall remodelling enzymes Pga4, Phr1, Phr2, Pir1 and Xog1 (95).

The availability of essential micronutrients such as iron and zinc also varies between host niches, and this is exacerbated by the host's attempts to deprive invading pathogens of these micronutrients via nutritional immunity (96-98). Therefore, the ability to scavenge iron and zinc is critical for fungal pathogenicity and tissue invasion $(99,100)$. In C. albicans, adaptation to iron starvation triggers changes in the expression of genes encoding cell wall proteins, biosynthetic enzymes and cross-linking enzymes (e.g. Als2, Bgl2, Cht2, Mnt4, Phr2, Pir1, Scw11) (101) and the elevation of Hwp1 and Rbt5 in the cell wall proteome (19). Recent data from our laboratory has shown that iron limitation is also accompanied by significant changes in cell wall architecture (unpublished). Changes in zinc availability also affect the C. albicans cell wall. Adaptation to zinc deprivation yields more adherent $C$. albicans cells that expose less mannan, but more chitin at their cell surface (102). Also, zinc mobilisation is linked to PKA signalling (103), which influences cell wall remodelling (59).

Host niches also vary significantly in their ambient $\mathrm{pH}$. For example, the bloodstream is maintained at around $\mathrm{pH} 7.4$, whereas the vaginal mucosa varies from $\mathrm{pH} 4$ to $\mathrm{pH} 5(1,104)$, and the major compartments of the gastrointestinal tract range from $\mathrm{pH} 2$ to $\mathrm{pH} 7.5$ (105-107). This type of change in ambient $\mathrm{pH}$ has a significant effect upon the $C$. albicans cell wall. When cells are exposed to low $\mathrm{pH}$, the chitin content of the cell wall increases and the mannan fibrils in the outer layer of the cell wall become shorter and more disorganised (108). The expression of cell wall protein genes is also affected by changes in ambient $\mathrm{pH}$. For example, exposure to alkaline pHs leads to the up-regulation of genes encoding cell wall biosynthetic enzymes (Kre6, Ecm38), modifying enzymes (Cht2, Crh1, Phr1), adhesins (Als3, Hwp1) and other cell wall mannoproteins (Hyr1, Rbt1, Rbt4) (109-111). Growth at an alkaline $\mathrm{pH}$ also induces the expression of cell wall and secreted proteins that play important roles in host-fungus interactions, such as the zincophore Pra1 and the candidalysin precursor, Ece1 $(100,111,112)$.

Oxygen levels vary dramatically between host niches, approaching zero in the human colon and in some fungal lesions (113-115). Adaptation to hypoxia drives changes to the architecture of the $C$ albicans cell wall (Figure 3 ), yielding a thinner inner glucan-chitin layer and thinner mannan outer layer (64). Hypoxia up-regulates ECM33, which is important for cell wall biogenesis and integrity (116), and $A L G 2$, which encodes a putative mannosyltransferase (117). There is also an increase in the abundance of specific GPI-anchored proteins in the cell wall proteome (Hwp1, Pir1, Rbt5) (19). Hypoxic regulation of cell wall changes depend largely upon a combination of mitochondrial, PKA and Efg1 signalling $(64,117)$.

Changes in ambient temperature also affect the $C$. albicans cell wall. When $C$. albicans yeast cells grow at $42^{\circ} \mathrm{C}$ their chitin content increases relative to cells grown at $30^{\circ} \mathrm{C}(118)$. Furthermore, the levels of the cell wall $\beta$-glucan glycosidases, Phr1 and Phr2, and chitin transglycosidases, Crh11 and Utr2, increase during growth at $42^{\circ} \mathrm{C}$ (118). In addition, temperature has an effect on the branched $N$-mannan composition of the cell wall: there is a decrease in $\beta$-1,2-linked mannose and an increase in $\alpha-1,3$-linked mannose during growth at higher temperatures (119). Unsurprisingly, the perturbation of thermal regulatory processes in C. albicans also affects the cell wall. For example, depletion of the molecular chaperone Hsp90, which regulates the transcription factor Hsf1, affects the chitin content of the cell wall and leads to an increase in the thickness of both the inner and outer layers of the wall (120).

As discussed above, exposure to antifungal drugs or to cell wall stresses triggers cell wall remodelling. Other types of environmental stress also affect the cell wall. $C$. albicans is exposed to oxidative stress during phagocytic attack, and the cell wall provides a first line of 
defence against the oxidative damage caused by reactive oxygen species (ROS). ROS detoxifying enzymes such as superoxide dismutases (Sod4, Sod5) and catalase (Cat1) are found at the cell surface $(121,122)$. Furthermore, the peroxidase Tsa1 is localised to the hyphal cell wall (123). All of these are up-regulated upon encountering oxidative stress (122124). Oxidative stress also influences cell wall architecture by inducing elongation of $\beta-1,2-$ linked mannose side chains (125).

Changes in osmolarity drive changes in cell volume. Under these circumstances, the elasticity of the cell wall underlies the ability of $C$. albicans cells to adjust their volume without incurring fatal rupturing of the wall or plasma membrane (18). This cell wall elasticity is dependent on the expression of the CHR family of transglycosylases (Chr11, Chr12, Utr2) (18). Adaptation to osmotic shock is dependent on signalling through the MAP kinases Hog1 and Mkc1, both of which regulate cell wall synthesis and remodelling $(75,126-128)$ (Figure 2).

Quorum sensing also influences cell wall biogenesis by modulating yeast hypha morphogenesis and PKA signalling at high cell densities (Figure 2). C. albicans generates farnesol, which accumulates at high cell densities. Farnesol attenuates the activity of adenyl cyclase, thereby down-regulating PKA activity (129). Farnesol also inhibits hyphal development by blocking Ubr1-mediated protein degradation of Nrg1, which represses hyphal development $(130,131)$.

Clearly the cell wall is a flexible organelle that responds to local environmental inputs. These adaptive changes in cell wall structure and organisation directly affect the fitness of the fungus in these microenvironments. However, they also affect the fitness of the fungus indirectly in these microenvironments by influencing host-fungus interactions (below).

\section{The cell wall in immune surveillance}

As mentioned above, the cell wall is the first point of direct contact between $C$. albicans cells and innate immune cells. The cell wall polymers chitin, $\beta$-glucan and mannan are present on diverse fungal pathogens (13). The immune system has evolved to recognise these cell wall polymers as key epitopes, or pathogen-associated molecular patterns (PAMPs) (132). Professional phagocytes (including neutrophils, macrophages and dendritic cells) and nonprofessional phagocytes (such as epithelial and endothelial cells) express an array of fungalsensing receptors, or pattern recognition receptors (PRRs) $(133,134)$. These host receptors detect $C$. albicans PAMPs, many of which are located at the cell surface, and this recognition elicits innate immune responses (135-137).

Chitin is located in the inner layer of the $C$. albicans cell wall, in relatively low abundance compared to the other main cell wall components. Consequently most of the chitin in the lateral cell wall is largely shielded by the outer layer of mannan fibrils. Nevertheless, chitin is exposed at the cell surface in bud/birth scars and at sites of cell wall damage and does act as a PAMP (132). Chitin is thought to undergo degradation into small particles ( $<1 \mathrm{um})$ during the inactivation of fungal cells by neutrophils and macrophages and by chitinase digestion (138). These chitin particles are recognised by the mannose receptor (MR) and, thereafter, intracellularly by NOD2 and TLR9, eliciting an anti-inflammatory programme that includes elevated IL-10 expression and the dampening of TNF-a levels (138). Furthermore, C. albicans chitin suppresses the generation of nitric oxide by macrophages and shifts macrophage polarization from a pro-inflammatory M1 state towards anti-inflammatory M2 activation (139).

$\beta$-Glucan is highly immunogenic and the recognition of this PAMP is critical for antifungal immunity. While most $\beta$-glucan is buried in the inner layer of the $C$. albicans cell wall and masked by mannan fibrils $(56,140)$, some $\beta$-glucan is exposed at bud scars and at small 
puncta over the lateral cell surface (89; Bain et al. unpublished). $\beta$-Glucan recognition occurs predominantly through the C-type lectin receptor (CLR), Dectin-1 (133). Dectin-1 mediated recognition of $\beta$-glucan promotes formation of a phagocytic synapse, which activates proinflammatory signalling through Syk/CARD9, driving the respiratory burst and the release of cytokines such as TNF- $\alpha$, IL- 6 and IL-12 (141). In addition, the recognition of $\beta$-glucan by Dectin-1 triggers phagocytosis, phagosome maturation and ultimately clearance of the offending fungal cell (142).

The critical importance of Dectin-1 in anti-Candida immunity is highlighted by the susceptibility of Dectin1 knockout mice to lethal infection (143), as well as by the association of a genetic polymorphism in human Dectin-1, which disrupts $\beta$-glucan recognition by phagocytes and abrogates cytokine expression, with familial recurrent vulvovaginal candidiasis (144). Furthermore, elevated $\beta$-glucan exposure on $C$. albicans cells correlates with their reduced fitness in the gastrointestinal tract (145), probably because this exposure enhances Dectin-1-mediated clearance of the fungal cells from the gut. In addition to activating phagocytosis and pro-inflammatory functions, Dectin-1-mediated sensing of C. albicans $\beta$-glucan enables "trained immunity" via epigenetic reprogramming of monocyte metabolism to drive enhanced protection against secondary infections (146). Also, a link to adaptive immunity was demonstrated in a study showing that Dectin-1 expressed on dendritic cells controls CD4+ T cell-mediated gut immunity in mice (147).

These observations illustrate the central importance of Dectin-1 in anti-Candida innate and adaptive immune defences. However, additional receptors contribute to the recognition of $\beta$-glucan. CR3 (Mac1, CD11b/CD18) is an integrin expressed on several myeloid and lymphoid cell types with affinity for a variety of ligands including iC3b-opsonized target cells (148). The I-domain of the CD11b subunit can bind $\beta$-glucan (149) and contributes, along with Dectin-1, to the recognition of $C$. albicans hyphae by macrophages (150). Other $\beta$-glucan receptors include the glycosphingolipid Lactosylceramide, the scavenger receptors SCARF and CD36, and CD23 (151-153).

As stated above, the frond-like mannan fibrils that decorate the outer cell wall limit the exposure of $\beta$-glucan to immune recognition (56). Nevertheless, the mannan fibrils themselves contain molecular signatures that potentiate host immune responses (132). Nmannan is detected by the mannose receptor, which promotes the oxidative burst and Th1/Th17 responses to control C. albicans infection (154). DC-SIGN (SIGN-R in mice), which is expressed by dendritic cells, also binds fungal $N$-mannan. This leads to interactions with plasma membrane "pickets", such as CD44, that connect the N-mannan-DC-SIGN synapse to the cytoskeleton, thereby stabilising phagocytic binding to the target $C$. albicans cells (155).

The PRRs Dectin-2 and Dectin-3 (MCL, ClecSF8) recognise hyphal a-mannan (156158). Indeed, hetero-dimerization of Dectin-2 with Dectin-3 drives a more potent NFkB response than either of these receptors alone (158). The Mincle (macrophage inducible $\mathrm{Ca}^{++}-$ dependent lectin) receptor also recognises a-mannan in the $C$. albicans cell wall to drive TNFa production, thereby promoting protection against systemic infection in mice $(137,159)$. In humans, Mincle expression on monocytes is non-phagocytic, but drives pro-inflammatory responses, whereas Mincle expression on neutrophils mediates phagocytosis and killing of C. albicans (160). C. albicans a-mannans are also recognised by CD23, resulting in NFkB activation (153).

Mannose-binding lectin (MBL) is a secreted circulatory PRR that supports opsonophagocytosis, and mice that lack MBL succumb to lethal $C$. albicans infections (161). Gut epithelial cells secrete MBL upon sensing $C$. albicans to regulate gut homeostasis and control infection (162). Galectin-3, which is expressed in the cytoplasm of host cells and in body fluids 
(163), has direct fungicidal activity against $C$. albicans cells (164). Galectin-3 binds fungal $\beta-$ 1,2 mannoside residues, which are found in phospholipomannan and occasional side branch caps of $N$-mannan chains in the outer wall of $C$. albicans (165). Meanwhile the PRR Langerin recognises mannan and $\beta$-glucan and is the dominant receptor on Langerhans cells, which are specialised dendritic cells that are positioned within the epidermis to sample Candida species during gut colonisation $(166,167)$.

The role of Toll-Like Receptors (TLRs) in mammalian antifungal defences was initially suggested by a Drosophila melanogaster study that revealed the regulation of drosomycin by the Toll pathway (168). Subsequently, TLR2 and TLR4 were shown to modulate cytokine production during candidiasis (169). These TLR receptors recognise phospholipomannan and O-linked mannan in the C. albicans cell wall, respectively (170-172).

Host receptors do not act efficiently in isolation. Instead, sensing of fungal targets is best achieved by collaboration between PRRs and the multi-valent engagement of multiple PAMPs on the cell surface. The inflammatory programme is maximised by co-stimulation of TLR and CLR and activation of MyD88 and Syk/CARD9 pathways, respectively. For example, Dectin-1 and TLR2 cooperate to drive TNF- $\alpha$ production following recognition of $C$. albicans $\beta$-glucan $(173,174)$. Dectin-1 also mediates cooperative signalling with CR3 and SIGN-R1 $(175,176)$ and, as mentioned above, the paired engagement of Dectin-2 and Dectin-3 synergistically boosts inflammatory responses (158). Our understanding of fungal recognition, combinatorial signalling and effector function is limited, and this is further complicated by the context of immune cells involved, their activation status and the nature of the fungal target encountered.

\section{The cell wall in immune evasion}

Most studies of fungal immunology have focussed on the immune cell - the receptors and their ligands, mechanisms of intracellular and cytokine signalling, and phagocytosis, for example. Less attention has been paid to the fungus and in particular to the impact of fungal adaptation upon PAMP exposure. Indeed most fungal immunology studies have examined fungal cells that were grown under standardised, but non-physiological conditions in vitro. Yet, as described above, $C$. albicans remodels its cell wall in response to environmental change. It is therefore unsurprising that the conditions under which $C$. albicans is grown significantly affect PAMP exposure, and thereby, the outcome of host-fungus interactions (91). It is becoming clear that, in reality, $C$. albicans is a moving target for the immune system.

Early indications that $C$. albicans is a moving immunological target arose from Wheeler's work showing that dynamic morphogenetic changes during infection affect the degree of $\beta$ glucan exposure on the fungal cells (177). In part this effect appears to be mediated by the damage that neutrophil extracellular traps cause to the fungal cell surface in situ, and the subsequent fungal cell wall remodelling and repair, which is largely mediated by Hog1dependent processes (178).

The paradigm of the moving immunological target was clearly demonstrated by the observation that exposing $C$. albicans cells to physiological levels of lactate (a metabolite generated in the vagina and gut by host cells and the microbiota) triggers $\beta$-glucan masking at the fungal cell surface (179). C. albicans cells detect extracellular lactate via the receptor Gpr1, which signals through Gpa2, PKA, Crz1 and Ace2, leading to reduced $\beta$-glucan exposure at the cell surface $(64,179)$ (Figure 3 ). This results in decreased macrophage phagocytosis, lower rates of neutrophil recruitment to sites of infection, and decreased production of the pro-inflammatory cytokines TNF- $\alpha$ and MIP-1 (179). This work, together with the correlative studies of Sem and co-workers (145), suggests that $C$. albicans exploits local 
environmental signals to evade immune recognition and thereby enhance its fitness in certain host niches.

More recently, $C$. albicans has been shown to trigger $\beta$-glucan masking and immune evasion in response to hypoxia $(64,115)$. During the development of a lesion, oxygen concentrations are lower through the combined activities of the infecting $C$. albicans cells and the neutrophils in immune infiltrates that form in an attempt to clear these fungal cells. The resultant hypoxic microenvironment activates $\beta$-glucan masking by the $C$. albicans cells, thereby protecting them from clearance by the surrounding neutrophils (115). The hypoxic signal is transduced via the mitochondrion, which leads to PKA-mediated $\beta$-glucan masking (64) (Figure 3). More recently, we have shown that iron depletion also promotes $\beta$-glucan masking in C. albicans (Pradhan et al. unpublished). Iron depletion is highly relevant to systemic infection as the fungus becomes exposed to iron-limiting conditions in tissues as a consequence of the nutritional immunity imposed by immune infiltrates around fungal lesions (98). Clearly, C. albicans is able to exploit the local signals in certain host niches to evade immune recognition.

Other host niches appear to trigger PAMP exposure and inflammation, rather than PAMP masking and immune evasion. $C$. albicans cells that are exposed to the relatively low ambient $\mathrm{pH}$ of the human vagina tend to expose higher levels of $\beta$-glucan and chitin at their surface than cells grown at neutral $\mathrm{pH}$ of the bloodstream, for example (108). The elevated chitin exposure appears to be mediated by a reduction in chitinase (Cht2) expression via Bcr1 and Rim101 signalling (Figure 3). The exposed fungal cells are phagocytosed more efficiently by macrophages and neutrophils, they stimulate increased production of pro-inflammatory cytokines, and they recruit immune cells more efficiently to infection sites (108). These observations appear to resonate with the inflammatory behaviour of $C$. albicans during vulvovaginal candidiasis (180).

Artificial environmental inputs, such as antifungal drugs, also convert $C$. albicans into a moving immunological target. Exposure to sub-inhibitory concentrations of caspofungin increases $\beta$-glucan exposure in $C$. albicans to sufficient levels to elicit a potent TNF- $\alpha$ response from macrophages (140). This caspofungin-mediated $\beta$-glucan exposure is relevant in vivo during infection (177). A heightened immune response to $C$. albicans can also be caused by mannan grazing by Bacteroidetes (a Gram-negative member of the gut microbiota), possibly via trimming of the outer fibrillar layer of the cell wall to reveal the underlying $\beta$-glucan (181).

\section{Parallels with other fungal pathogens}

C. albicans is not the only fungal pathogen to evade host immune responses by masking a major PAMP in their cell wall. A. fumigatus, C. neoformans, Histoplasma capsulatum, and other dimorphic fungal pathogens have evolved effective mechanisms to avoid Dectin-1mediated immune responses. These fungal pathogens mask PAMPs via two major mechanisms: firstly, by physically masking the PAMP with non-stimulatory cell wall molecules; or secondly, by hydrolase-mediated remodelling of the exposed PAMP.

A. fumigatus is the most common cause of invasive mould infections in immunocompromised patients (7). The initial host-pathogen interaction, and an important stage for immune evasion, occurs between conidia, lung epithelial cells, and resident alveolar macrophages. The $A$. fumigatus cell wall contains pro-inflammatory PAMPs, such as galactomannans and $\beta$-glucan, which stimulate robust antifungal immune responses and clearance mechanisms (182-184). A. fumigatus PAMP exposure peaks with conidial swelling and early hyphal germination, but is masked in mature hyphae and ungerminated conidia 
(185). These ungerminated conidia mask their cell wall PAMPs under a rodlet layer composed of DHN-melanin and the hydrophobic RodA protein (186).

RodA masks Dectin-1- and Dectin-2-mediated detection of A. fumigatus conidial PAMPs, and this promotes early immune evasion and fungal survival in the host (187). DHNmelanin plays an important role in preventing phagosomal acidification, thereby enhancing virulence $(188,189)$. However, DHN-melanin is also a PAMP and the ligand for the newly characterised host PRR, MelLec (184). Sensing of DHN-melanin by MelLec is important for the control of systemic $A$. fumigatus infection and MelLec polymorphisms are associated with increased risk of aspergillosis in certain cohorts of transplant patients (184).

The protective rodlet layer is lost during $A$. fumigatus germination to reveal the underlying PAMPs. However, A. fumigatus hyphae synthesize a cell wall polysaccharide, galactosaminogalactan, which masks $\beta$-glucan whilst mediating adherence to host cells (190). A. fumigatus mutants with defects in galactosaminogalactan biosynthesis display increased $\beta$-glucan exposure, they are attenuated in their virulence, and they induce hyper-inflammation in mice (190).

C. neoformans is another environmentally prevalent human fungal pathogen that causes disease in immunocompromised patients $(7,191)$. Despite its clinical significance, relatively little is known about how the immune system recognises $C$. neoformans (192). In addition to the conserved carbohydrate polymers that typically form fungal cell walls (e.g. chitin, $\beta$ glucans, and mannans (13), C. neoformans possesses a unique polysaccharide capsule, primarily composed of glucuronoxylomannan, which masks its cell wall PAMPs. Glucuronoxylomannan is recognised by the receptor TLR4, but TLR4 engagement is not sufficient to induce TNF- $\alpha$ or influence mouse susceptibility to cryptococcosis $(193,194)$. Interestingly, the collectin SP-D binds to glucuronoxylomannan in vitro, and its interaction with C. neoformans cells facilitates fungal protection from macrophage killing (195). This suggests a possible proactive immune evasion role for $C$. neoformans capsule beyond simply passively shielding cell wall PAMPs (195).

Acapsular $C$. neoformans mutants are avirulent and are phagocytosed more efficiently than encapsulated cells (195), which is likely due to the unmasking of the underlying immunestimulatory PAMPs. These appear to include mannoprotein moieties recognised by the Mannose Receptor (196), as mice lacking the Mannose Receptor are more susceptible to infection than wild-type mice (197). Other major receptors, such as Dectin-1, Dectin-2, and Dectin-3, are not essential for in vivo defences against cryptococcosis (198-200).

The virulence of dimorphic fungal pathogens, such as $H$. capsulatum, Blastomyces dermatitidis and Paracoccidioides brasiliensis, has been linked to $\alpha-1,3$-glucan in their cell walls. $\alpha-1,3-$-Glucan blocks the recognition of cell wall $\beta-1,3$-glucan via Dectin-1 by physically masking $\beta-1,3$-glucan (201). Consequently, $P$. brasiliensis and $B$. dermatitidis mutants with low $\alpha-1,3-$ glucan production display decreased virulence in mouse models of infection $(202,203)$. However, this association between $H$. capsulatum virulence and $\alpha-1,3-$ glucan is dependent on strain chemotype. $H$. capsulatum strains of chemotype II require $\alpha-1,3$-glucan for virulence (204) and the inactivation of $\alpha-1,3-$ glucan synthesis attenuates $H$. capsulatum virulence in mice (205).

In addition to physically masking $\beta-1,3-$ glucan with $\alpha-1,3-$ glucan, $H$. capsulatum also enzymatically reduces $\beta$-glucan exposure in its cell wall (206). This is achieved by expressing Eng1, an endoglucanase that hydrolyses $\beta$-(1,3)-glycosyl linkages. Eng1 decreases $\beta$-glucan exposure at the cell surface, thereby reducing Dectin-1-mediated recognition of $H$. capsulatum cells, and enhancing the virulence of $H$. capsulatum (206). Therefore the combined effects of physical masking (via $\alpha-1,3-$ glucan) and enzymatic trimming (via Eng1) provide $H$. capsulatum 
with effective PAMP masking mechanisms (Figure 3). No doubt these contribute to the inability of innate immune cells to control $H$. capsulatum infection, with macrophages ultimately serving as a reservoir for disseminated infection (206). Interestingly, Eng1 homologs exist in other important fungal pathogens, including C. albicans, suggesting that PAMP trimming mechanisms might contribute to immune evasion in these fungi.

\section{Conclusions and outlook}

To summarise, the fungal cell wall is a remarkable organelle that retains a high degree of elasticity and permeability, whilst retaining sufficient tensile strength and spatial integrity to preserve the morphology of the cell. In this way the cell wall is able to protect the fungal cell against certain acute environmental stresses, whilst permitting communication with the host or local microbiota through the release of large extracellular vesicles. Furthermore, through a complex signalling network that regulates cellular adaptation and cell wall synthesis, the cell wall is responsive to a wide variety of environmental challenges. This cell wall remodelling allows a fungal pathogen to evade the potentially lethal effects of certain antifungal drugs or debilitating mutations, and of local cell wall stresses imposed by host niches.

However, the cell wall is also a point of fragility for a fungal pathogen, as it carries immuno-stimulatory epitopes that can trigger antifungal host defences. Therefore the cell wall has a major influence upon host-fungus interactions. Nevertheless, the ability to remodel the cell wall has provided fungal pathogens with the capacity to evolve effective immune evasion strategies that either mask or remove cell surface PAMPs. C. albicans, in particular, has "learned" to exploit a variety of host-derived signals to activate $\beta$-glucan masking and immune evasion, including lactate, iron deprivation and hypoxia.

A number of fascinating questions remain to be answered. For example, what is the exact nature and frequency of the covalent cross-links between the major cell wall polymers in the $C$. albicans cell wall? And how, together with the properties of these polymers, do these cross-links promote the remarkable elasticity and morphological stability of the cell wall? The development of monoclonal or recombinant antibodies that are specific for particular crosslinks would permit the frequency and spatial distribution of these linkages to be analysed in situ on the C. albicans cell wall. This would be particularly interesting in the context of environmental or genetic changes that affect cell wall elasticity and/or morphology (e.g. $(18,20,46,48)$.

It would be fascinating to screen for host inputs that influence $\beta$-glucan exposure in $C$. albicans and thereby affect immune evasion. A number of specific host inputs have been identified already, but an unbiased screen of host signals has yet to be reported. Then, given the complexity and diversity of host niches, it would be important to test combinations of inputs to establish which signals are most influential in particular niches, and to test PAMP exposure on cells isolated directly from these niches. For example, recent data (e.g. (207) suggests that lactate-mediated $\beta$-glucan masking might dominate over $\mathrm{pH}$-mediated $\beta$-glucan exposure during vulvovaginal infection. But what signals dominate in the gastrointestinal tract, and how does this affect $C$. albicans colonisation of the colon, for example?

It is also important to understand exactly how do $C$. albicans cells mask $\beta$-glucan at their cell surface - by covering it with mannan or by trimming via an Eng1-like activity $(56,208)$ ? Does $\beta$-glucan masking attenuate $C$. albicans-phagocyte interactions by simply delaying phagocytic recognition, or does masking (also) reduce the dynamics of phagocytic uptake and/or phagolysosomal maturation? 
These questions are not simply of academic interest. A better understanding of the intricacies of cell wall structure and biogenesis is likely to reveal new therapeutic targets that will compromise this essential organelle. Furthermore, a better understanding of the immune evasion strategies exploited by fungal pathogens might reveal ways in which PAMP masking might be blocked. This type of drug might provide a potential means of augmenting antifungal immunotherapies. Time will tell.

\section{Acknowledgements}

This work was funded by a programme grant from the UK Medical Research Council [www.mrc.ac.uk: MR/M026663/1], and by PhD studentships from the University of Aberdeen to AP, DL. The work was also supported by the Medical Research Council Centre for Medical Mycology and the University of Aberdeen (MR/N006364/1) and by the Wellcome Trust [www.wellcome.ac.uk: 097377]. The funders had no role in study design, data collection and analysis, decision to publish, or preparation of the manuscript.

\section{FIGURE LEGENDS}

Figure 1: Architecture of the $\boldsymbol{C}$. albicans cell wall. The model of the cell wall structure illustrates the organisation of chitin and glucan in the inner cell wall, and the $N$-mannan fibrils of the outer cell wall, which are linked to the inner cell wall via the GPI-anchored proteins from which these fibrils radiate. GPI-proteins are attached to $\beta-1,6$-glucan which, in turn, is linked to $\beta-1,3$-glucan, whereas Pir proteins are linked directly to $\beta-1,3-$ glucan. The cartoon, which is taken with permission from (13), is compared with a transmission electron micrograph of the C. albicans cell wall (upper panel), which is an expanded region (blue box) from a micrograph of a complete cell (lower panel). The diameters of inner and outer layers of the cell wall are each about $0.14 \mu \mathrm{m}$ across (64).

Figure 2: A complex network of signalling pathways regulates cell wall synthesis and remodelling in $C$. albicans. Cell wall remodelling depends on the cell integrity pathway (red) $(74,75)$. Cell wall damage is thought to be detected by Wsc1/2/4, which activates protein kinase C (Pkc1) via Rho1. This leads to activation of the Mkc1 MAPK module which triggers cell wall remodelling via the transcription factor RIm1 but primarily via Cas $5(76,77,209)$. The Hog1 pathway (blue) also contributes to the control of cell wall synthesis and remodelling (59). Cell wall or osmotic stress down-regulates SIn1, which leads to the activation of the Hog1 MAPK module via the Ypd1 and Ssk1 phosphorelay $(126,127,210,211)$. Hog1 then modulates cell wall largely via the transcription factor Sko1, which also represses Brg1 (212). Hog1 is down-regulated by the phosphatases Ptp2/3, which are activated by TOR signalling (grey) (212). Hog1 also activates Mkc1 signalling, and represses the Cek1 pathway (dark green) (213). Msb2 acts in concert with Sho1 to activate the Cek1 pathway in response to osmotic stress or cell wall damage, and Opy2 also contributes to Cek1 activation via Cst20 (214-217). Cek1 activates Cph1 which is thought to contribute to cell wall remodelling during hyphal development. Morphogenesis is also activated by cAMP-PKA signalling (purple), which leads to cell wall remodelling. In response to a variety of environmental inputs, the Gpr1-Gpa2 and Ras modules activate adenyl cyclase (Cyr1), which leads to cAMP accumulation and inactivation of the PKA regulatory subunit Bcy1 (218). This leads to activation of the PKA catalytic subunits (Tpk1, Tpk2) which stimulates a network of transcription factors (Efg1, 
Ume6, Brg1) and releases Nrg1-Tup1-mediated repression to activate hypha-specific genes, hyphal development and cell wall remodelling $(27,85-87,219)$. This pathway is repressed by quorum sensing (brown), which inhibits adenyl cyclase (Cyr1), and also stabilises the repressor Nrg1 via Ubr1, Cup9 and Sok1 $(129,130,220)$. Calcium $\left(\mathrm{Ca}^{++}\right)$- camodulin $(\mathrm{Cmd} 1)$ - calcineurin $(\mathrm{Cna} / \mathrm{b})$ signalling (lime green) also plays an important role in cell wall remodelling $(59,221,222)$. Activation of this pathway, possibly via the stretch-activated channel Mid1, leads to the up-regulation of the transcription factor Crz1, which promotes cell wall remodelling $(223,224)$.

Figure 3: Environmental factors modulate the exposure of cell surface epitopes to promote immune evasion or inflammation. A number of factors have been shown to influence the exposure of key epitopes (PAMPs) on the $C$. albicans cell surface. Caspofungin treatment leads to $\beta$-glucan exposure via the cell integrity (Mkc1) pathway (red) $(140,177)$. In contrast, host-derived lactate triggers $\beta$-glucan masking via Gpr1-Gpa2 and PKA signalling (purple) $(64,179)$. Hypoxia also initiates $\beta$-glucan masking, but this is mediated by mitochondrial signalling (grey), which then activates the PKA pathway (purple) (64). Micronutrient depletion leads to morphological changes that coincide with elevated chitin exposure at the cell surface (102). This might be transduced via PKA signalling (103). Growth in acidic pHs leads to increased $\beta$-glucan and chitin exposure (108). The increase in chitin exposure is mediated by Bcr1 and Rim101 signalling (108).

\section{REFERENCES}

(1) Sobel JD. Vulvovaginal candidosis. Lancet 2007 Jun 9;369(9577):1961-1971.

(2) Hertel M, Schmidt-Westhausen AM, Strietzel FP. Local, systemic, demographic, and health-related factors influencing pathogenic yeast spectrum and antifungal drug administration frequency in oral candidiasis: a retrospective study. Clin Oral Investig 2016 Sep;20(7):1477-1486.

(3) Denning DW, Kneale M, Sobel JD, Rautemaa-Richardson R. Global burden of recurrent vulvovaginal candidiasis: a systematic review. Lancet Infect Dis 2018 Aug 2.

(4) Perlroth J, Choi B, Spellberg B. Nosocomial fungal infections: epidemiology, diagnosis, and treatment. Med Mycol 2007 Jun;45(4):321-346.

(5) Gouba N, Drancourt M. Digestive tract mycobiota: a source of infection. Med Mal Infect 2015 Jan-Feb;45(1-2):9-16.

(6) Odds FC, Brown AJ, Gow NA. Antifungal agents: mechanisms of action. Trends Microbiol 2003 Jun;11(6):272-279.

(7) Brown GD, Denning DW, Gow NA, Levitz SM, Netea MG, White TC. Hidden killers: human fungal infections. Sci Transl Med 2012 Dec 19;4(165):165rv13.

(8) Kullberg BJ, Arendrup MC. Invasive Candidiasis. N Engl J Med 2015 Oct 8;373(15):1445-1456.

(9) Gow NAR, Latge JP, Munro CA. The Fungal Cell Wall: Structure, Biosynthesis, and Function. Microbiol Spectr 2017 May;5(3):10.1128/microbiolspec.FUNK-0035-2016. 
(10) Douglas CM, D'Ippolito JA, Shei GJ, Meinz M, Onishi J, Marrinan JA, et al. Identification of the FKS1 gene of Candida albicans as the essential target of 1,3-beta-D-glucan synthase inhibitors. Antimicrob Agents Chemother 1997 Nov;41(11):2471-2479.

(11) Munro CA, Gow NA. Chitin synthesis in human pathogenic fungi. Med Mycol 2001;39 Suppl 1:41-53.

(12) Munro CA, Winter K, Buchan A, Henry K, Becker JM, Brown AJ, et al. Chs1 of Candida albicans is an essential chitin synthase required for synthesis of the septum and for cell integrity. Mol Microbiol 2001 Mar;39(5):1414-1426.

(13) Erwig LP, Gow NA. Interactions of fungal pathogens with phagocytes. Nat Rev Microbiol 2016 Mar;14(3):163-176.

(14) Nguyen TH, Fleet GH, Rogers PL. Composition of the cell walls of several yeast species. Appl Microbiol Biotechnol 1998 Aug;50(2):206-212.

(15) Sudbery PE. Growth of Candida albicans hyphae. Nat Rev Microbiol 2011 Aug 16;9(10):737-748.

(16) Vargas G, Rocha JD, Oliveira DL, Albuquerque PC, Frases S, Santos SS, et al. Compositional and immunobiological analyses of extracellular vesicles released by Candida albicans. Cell Microbiol 2015 Mar;17(3):389-407.

(17) Walker L, Sood P, Lenardon MD, Milne G, Olson J, Jensen G, et al. The Viscoelastic Properties of the Fungal Cell Wall Allow Traffic of AmBisome as Intact Liposome Vesicles. MBio 2018 Feb 6;9(1):10.1128/mBio.02383-17.

(18) Ene IV, Walker LA, Schiavone M, Lee KK, Martin-Yken H, Dague E, et al. Cell Wall Remodeling Enzymes Modulate Fungal Cell Wall Elasticity and Osmotic Stress Resistance. MBio 2015 Jul 28;6(4):e00986-15.

(19) Sosinska GJ, de Groot PWJ, Teixeira de Mattos MJ, Dekker HL, de Koster CG, Hellingwerf $\mathrm{KJ}$, et al. Hypoxic conditions and iron restriction affect the cell-wall proteome of Candida albicans grown under vagina-simulative conditions. Microbiology 2008 Feb;154(Pt 2):510-520.

(20) Ene IV, Adya AK, Wehmeier S, Brand AC, MacCallum DM, Gow NA, et al. Host carbon sources modulate cell wall architecture, drug resistance and virulence in a fungal pathogen. Cell Microbiol 2012 Sep;14(9):1319-1335.

(21) Hall RA. Dressed to impress: impact of environmental adaptation on the Candida albicans cell wall. Mol Microbiol 2015 Jul;97(1):7-17.

(22) Shepherd MG. Cell envelope of Candida albicans. Crit Rev Microbiol 1987;15(1):7-25.

(23) Klis FM, de Groot P, Hellingwerf K. Molecular organization of the cell wall of Candida albicans. Med Mycol 2001;39 Suppl 1:1-8.

(24) Bowman SM, Free SJ. The structure and synthesis of the fungal cell wall. Bioessays 2006 Aug;28(8):799-808.

(25) Lenardon MD, Whitton RK, Munro CA, Marshall D, Gow NA. Individual chitin synthase enzymes synthesize microfibrils of differing structure at specific locations in the Candida albicans cell wall. Mol Microbiol 2007 Dec;66(5):1164-1173.

(26) Lenardon MD, Munro CA, Gow NA. Chitin synthesis and fungal pathogenesis. Curr Opin Microbiol 2010 Aug;13(4):416-423. 
(27) Staniszewska M, Bondaryk M, Rabczenko D, Smolenska-Sym G, Kurzatkowski W. Cell wall carbohydrates content of pathogenic Candida albicans strain morphological forms. Med Dosw Mikrobiol 2013;65(2):119-128.

(28) Preechasuth K, Anderson JC, Peck SC, Brown AJ, Gow NA, Lenardon MD. Cell wall protection by the Candida albicans class I chitin synthases. Fungal Genet Biol 2015 Sep;82:264-276.

(29) Mio T, Adachi-Shimizu M, Tachibana Y, Tabuchi H, Inoue SB, Yabe T, et al. Cloning of the Candida albicans homolog of Saccharomyces cerevisiae GSC1/FKS1 and its involvement in beta-1,3-glucan synthesis. J Bacteriol 1997 Jul;179(13):4096-4105.

(30) Kondoh O, Tachibana Y, Ohya Y, Arisawa M, Watanabe T. Cloning of the RHO1 gene from Candida albicans and its regulation of beta-1,3-glucan synthesis. J Bacteriol 1997 Dec;179(24):7734-7741.

(31) Kapteyn JC, Hoyer LL, Hecht JE, Muller WH, Andel A, Verkleij AJ, et al. The cell wall architecture of Candida albicans wild-type cells and cell wall-defective mutants. Mol Microbiol 2000 Feb;35(3):601-611.

(32) Umeyama T, Kaneko A, Watanabe H, Hirai A, Uehara Y, Niimi M, et al. Deletion of the CaBIG1 gene reduces beta-1,6-glucan synthesis, filamentation, adhesion, and virulence in Candida albicans. Infect Immun 2006 Apr;74(4):2373-2381.

(33) Chaffin WL. Candida albicans cell wall proteins. Microbiol Mol Biol Rev 2008 Sep;72(3):495-544.

(34) Buurman ET, Westwater C, Hube B, Brown AJ, Odds FC, Gow NA. Molecular analysis of CaMnt1p, a mannosyl transferase important for adhesion and virulence of Candida albicans. Proc Natl Acad Sci U S A 1998 Jun 23;95(13):7670-7675.

(35) Bates S, MacCallum DM, Bertram G, Munro CA, Hughes HB, Buurman ET, et al. Candida albicans Pmr1p, a secretory pathway P-type Ca2+/Mn2+-ATPase, is required for glycosylation and virulence. J Biol Chem 2005 Jun 17;280(24):23408-23415.

(36) Munro CA, Bates S, Buurman ET, Hughes HB, Maccallum DM, Bertram G, et al. Mnt1p and Mnt2p of Candida albicans are partially redundant alpha-1,2mannosyltransferases that participate in O-linked mannosylation and are required for adhesion and virulence. J Biol Chem 2005 Jan 14;280(2):1051-1060.

(37) Timpel C, Strahl-Bolsinger S, Ziegelbauer K, Ernst JF. Multiple functions of Pmt1pmediated protein O-mannosylation in the fungal pathogen Candida albicans. J Biol Chem 1998 Aug 14;273(33):20837-20846.

(38) Gatti E, Popolo L, Vai M, Rota N, Alberghina L. O-linked oligosaccharides in yeast glycosyl phosphatidylinositol-anchored protein gp115 are clustered in a serine-rich region not essential for its function. J Biol Chem 1994 Aug 5;269(31):19695-19700.

(39) Bates S, Hughes HB, Munro CA, Thomas WP, MacCallum DM, Bertram G, et al. Outer chain $\mathrm{N}$-glycans are required for cell wall integrity and virulence of Candida albicans. $\mathrm{J}$ Biol Chem 2006 Jan 6;281(1):90-98.

(40) Mora-Montes HM, Bates S, Netea MG, Castillo L, Brand A, Buurman ET, et al. A multifunctional mannosyltransferase family in Candida albicans determines cell wall mannan structure and host-fungus interactions. J Biol Chem $2010 \mathrm{Apr}$ 16;285(16):12087-12095. 
(41) Hall RA, Bates S, Lenardon MD, Maccallum DM, Wagener J, Lowman DW, et al. The Mnn2 mannosyltransferase family modulates mannoprotein fibril length, immune recognition and virulence of Candida albicans. PLoS Pathog 2013;9(4):e1003276.

(42) Hall RA, Gow NA. Mannosylation in Candida albicans: role in cell wall function and immune recognition. Mol Microbiol 2013 Dec;90(6):1147-1161.

(43) Hobson RP, Munro CA, Bates S, MacCallum DM, Cutler JE, Heinsbroek SE, et al. Loss of cell wall mannosylphosphate in Candida albicans does not influence macrophage recognition. J Biol Chem 2004 Sep 17;279(38):39628-39635.

(44) Murciano C, Moyes DL, Runglall M, Islam A, Mille C, Fradin C, et al. Candida albicans cell wall glycosylation may be indirectly required for activation of epithelial cell proinflammatory responses. Infect Immun 2011 Dec;79(12):4902-4911.

(45) Toh-e A, Yasunaga S, Nisogi H, Tanaka K, Oguchi T, Matsui Y. Three yeast genes, PIR1, PIR2 and PIR3, containing internal tandem repeats, are related to each other, and PIR1 and PIR2 are required for tolerance to heat shock. Yeast 1993 May;9(5):481-494.

(46) Pardini G, De Groot PW, Coste AT, Karababa M, Klis FM, de Koster CG, et al. The $\mathrm{CRH}$ family coding for cell wall glycosylphosphatidylinositol proteins with a predicted transglycosidase domain affects cell wall organization and virulence of Candida albicans. J Biol Chem 2006 Dec 29;281(52):40399-40411.

(47) Popolo L, Degani G, Camilloni C, Fonzi WA. The PHR Family: The Role of Extracellular Transglycosylases in Shaping Candida albicans Cells. J Fungi (Basel) 2017 Oct 29;3(4):10.3390/jof3040059.

(48) Fonzi WA. PHR1 and PHR2 of Candida albicans encode putative glycosidases required for proper cross-linking of beta-1,3- and beta-1,6-glucans. J Bacteriol 1999 Nov; 181(22):7070-7079.

(49) Staab JF, Bradway SD, Fidel PL, Sundstrom P. Adhesive and mammalian transglutaminase substrate properties of Candida albicans Hwp1. Science 1999 Mar 5;283(5407):1535-1538.

(50) Hoyer LL, Green CB, Oh SH, Zhao X. Discovering the secrets of the Candida albicans agglutinin-like sequence (ALS) gene family--a sticky pursuit. Med Mycol 2008 Feb;46(1):1-15.

(51) Hofs S, Mogavero S, Hube B. Interaction of Candida albicans with host cells: virulence factors, host defense, escape strategies, and the microbiota. J Microbiol 2016 Mar;54(3):149-169.

(52) Gow NA, Hube B. Importance of the Candida albicans cell wall during commensalism and infection. Curr Opin Microbiol 2012 Aug;15(4):406-412.

(53) Phan QT, Myers CL, Fu Y, Sheppard DC, Yeaman MR, Welch WH, et al. Als3 is a Candida albicans invasin that binds to cadherins and induces endocytosis by host cells. PLoS Biol 2007 Mar;5(3):e64.

(54) Almeida RS, Brunke S, Albrecht A, Thewes S, Laue M, Edwards JE, et al. the hyphalassociated adhesin and invasin Als3 of Candida albicans mediates iron acquisition from host ferritin. PLoS Pathog 2008 Nov;4(11):e1000217. 
(55) Dague E, Bitar R, Ranchon H, Durand F, Yken HM, Francois JM. An atomic force microscopy analysis of yeast mutants defective in cell wall architecture. Yeast 2010 Aug;27(8):673-684.

(56) Graus MS, Wester MJ, Lowman DW, Williams DL, Kruppa MD, Martinez CM, et al. Mannan Molecular Substructures Control Nanoscale Glucan Exposure in Candida. Cell Rep 2018 Aug 28;24(9):2432-2442.e5.

(57) Deatherage BL, Cookson BT. Membrane vesicle release in bacteria, eukaryotes, and archaea: a conserved yet underappreciated aspect of microbial life. Infect Immun 2012 Jun;80(6):1948-1957.

(58) Joffe LS, Nimrichter L, Rodrigues ML, Del Poeta M. Potential Roles of Fungal Extracellular Vesicles during Infection. mSphere 2016 Jun 29;1(4):10.1128/mSphere.00099-16. eCollection 2016 Jul-Aug.

(59) Munro CA, Selvaggini S, de Bruijn I, Walker L, Lenardon MD, Gerssen B, et al. The $\mathrm{PKC}, \mathrm{HOG}$ and $\mathrm{Ca} 2+$ signalling pathways co-ordinately regulate chitin synthesis in Candida albicans. Mol Microbiol 2007 Mar;63(5):1399-1413.

(60) Blankenship JR, Fanning S, Hamaker JJ, Mitchell AP. An extensive circuitry for cell wall regulation in Candida albicans. PLoS Pathog 2010 Feb 5;6(2):e1000752.

(61) Galan-Diez M, Arana DM, Serrano-Gomez D, Kremer L, Casasnovas JM, Ortega M, et al. Candida albicans beta-glucan exposure is controlled by the fungal CEK1-mediated mitogen-activated protein kinase pathway that modulates immune responses triggered through dectin-1. Infect Immun 2010 Apr;78(4):1426-1436.

(62) Leach MD, Stead DA, Argo E, MacCallum DM, Brown AJ. Molecular and proteomic analyses highlight the importance of ubiquitination for the stress resistance, metabolic adaptation, morphogenetic regulation and virulence of Candida albicans. Mol Microbiol 2011 Mar;79(6):1574-1593.

(63) Znaidi S, van Wijlick L, Hernandez-Cervantes A, Sertour N, Desseyn JL, Vincent F, et al. Systematic gene overexpression in Candida albicans identifies a regulator of early adaptation to the mammalian gut. Cell Microbiol 2018 Nov;20(11):e12890.

(64) Pradhan A, Avelar GM, Bain JM, Childers DS, Larcombe DE, Netea MG, et al. Hypoxia Promotes Immune Evasion by Triggering beta-Glucan Masking on the Candida albicans Cell Surface via Mitochondrial and cAMP-Protein Kinase A Signaling. MBio 2018 Nov 6;9(6):10.1128/mBio.01318-18.

(65) Walker LA, Munro CA, de Bruijn I, Lenardon MD, McKinnon A, Gow NA. Stimulation of chitin synthesis rescues Candida albicans from echinocandins. PLoS Pathog 2008 Apr 4;4(4):e1000040.

(66) Lee KK, Maccallum DM, Jacobsen MD, Walker LA, Odds FC, Gow NA, et al. Elevated cell wall chitin in Candida albicans confers echinocandin resistance in vivo. Antimicrob Agents Chemother 2012 Jan;56(1):208-217.

(67) Sorgo AG, Heilmann CJ, Dekker HL, Bekker M, Brul S, de Koster CG, et al. Effects of fluconazole on the secretome, the wall proteome, and wall integrity of the clinical fungus Candida albicans. Eukaryot Cell 2011 Aug;10(8):1071-1081.

(68) Gow NA, Robbins PW, Lester JW, Brown AJ, Fonzi WA, Chapman T, et al. A hyphalspecific chitin synthase gene (CHS2) is not essential for growth, dimorphism, or 
virulence of Candida albicans. Proc Natl Acad Sci U S A 1994 Jun 21;91(13):62166220.

(69) Albrecht A, Felk A, Pichova I, Naglik JR, Schaller M, de Groot P, et al. Glycosylphosphatidylinositol-anchored proteases of Candida albicans target proteins necessary for both cellular processes and host-pathogen interactions. J Biol Chem 2006 Jan 13;281(2):688-694.

(70) Plaine A, Walker L, Da Costa G, Mora-Montes HM, McKinnon A, Gow NA, et al. Functional analysis of Candida albicans GPI-anchored proteins: roles in cell wall integrity and caspofungin sensitivity. Fungal Genet Biol 2008 Oct;45(10):1404-1414.

(71) Richard M, Ibata-Ombetta S, Dromer F, Bordon-Pallier F, Jouault T, Gaillardin C. Complete glycosylphosphatidylinositol anchors are required in Candida albicans for full morphogenesis, virulence and resistance to macrophages. Mol Microbiol 2002 May;44(3):841-853.

(72) Moreno-Ruiz E, Ortu G, de Groot PW, Cottier F, Loussert C, Prevost MC, et al. The GPI-modified proteins Pga59 and Pga62 of Candida albicans are required for cell wall integrity. Microbiology 2009 Jun;155(Pt 6):2004-2020.

(73) Levin DE. Regulation of cell wall biogenesis in Saccharomyces cerevisiae: the cell wall integrity signaling pathway. Genetics $2011 \mathrm{Dec} ; 189(4): 1145-1175$.

(74) Paravicini G, Mendoza A, Antonsson B, Cooper M, Losberger C, Payton MA. The Candida albicans PKC1 gene encodes a protein kinase $C$ homolog necessary for cellular integrity but not dimorphism. Yeast 1996 Jun 30;12(8):741-756.

(75) Navarro-Garcia F, Alonso-Monge R, Rico H, Pla J, Sentandreu R, Nombela C. A role for the MAP kinase gene MKC1 in cell wall construction and morphological transitions in Candida albicans. Microbiology 1998 Feb;144 ( Pt 2)(Pt 2):411-424.

(76) Dichtl K, Samantaray S, Wagener J. Cell wall integrity signalling in human pathogenic fungi. Cell Microbiol 2016 Sep;18(9):1228-1238.

(77) Bruno VM, Kalachikov S, Subaran R, Nobile CJ, Kyratsous C, Mitchell AP. Control of the $\mathrm{C}$. albicans cell wall damage response by transcriptional regulator Cas5. PLoS Pathog 2006 Mar;2(3):e21.

(78) Fuchs BB, Mylonakis E. Our paths might cross: the role of the fungal cell wall integrity pathway in stress response and cross talk with other stress response pathways. Eukaryot Cell 2009 Nov;8(11):1616-1625.

(79) Garcia R, Bravo E, Diez-Muniz S, Nombela C, Rodriguez-Pena JM, Arroyo J. A novel connection between the Cell Wall Integrity and the PKA pathways regulates cell wall stress response in yeast. Sci Rep 2017 Jul 18;7(1):5703-017-06001-9.

(80) Donlin MJ, Upadhya R, Gerik KJ, Lam W, VanArendonk LG, Specht CA, et al. Cross talk between the cell wall integrity and cyclic AMP/protein kinase A pathways in Cryptococcus neoformans. MBio 2014 Aug 12;5(4):10.1128/mBio.01573-14.

(81) Valiante V, Macheleidt J, Foge M, Brakhage AA. The Aspergillus fumigatus cell wall integrity signaling pathway: drug target, compensatory pathways, and virulence. Front Microbiol 2015 Apr 16;6:325.

(82) Lo HJ, Kohler JR, DiDomenico B, Loebenberg D, Cacciapuoti A, Fink GR. Nonfilamentous C. albicans mutants are avirulent. Cell 1997 Sep 5;90(5):939-949. 
(83) Saville SP, Lazzell AL, Monteagudo C, Lopez-Ribot JL. Engineered control of cell morphology in vivo reveals distinct roles for yeast and filamentous forms of Candida albicans during infection. Eukaryot Cell 2003 Oct;2(5):1053-1060.

(84) Mukaremera L, Lee KK, Mora-Montes HM, Gow NAR. Candida albicans Yeast, Pseudohyphal, and Hyphal Morphogenesis Differentially Affects Immune Recognition. Front Immunol 2017 Jun 7;8:629.

(85) Ebanks RO, Chisholm K, McKinnon S, Whiteway M, Pinto DM. Proteomic analysis of Candida albicans yeast and hyphal cell wall and associated proteins. Proteomics 2006 Apr;6(7):2147-2156.

(86) Castillo L, Calvo E, Martinez Al, Ruiz-Herrera J, Valentin E, Lopez JA, et al. A study of the Candida albicans cell wall proteome. Proteomics 2008 Sep;8(18):3871-3881.

(87) Gil-Bona A, Parra-Giraldo CM, Hernaez ML, Reales-Calderon JA, Solis NV, Filler SG, et al. Candida albicans cell shaving uncovers new proteins involved in cell wall integrity, yeast to hypha transition, stress response and host-pathogen interaction. J Proteomics 2015 Sep 8;127(Pt B):340-351.

(88) Lowman DW, Greene RR, Bearden DW, Kruppa MD, Pottier M, Monteiro MA, et al. Novel structural features in Candida albicans hyphal glucan provide a basis for differential innate immune recognition of hyphae versus yeast. J Biol Chem 2014 Feb 7;289(6):3432-3443.

(89) Gantner BN, Simmons RM, Underhill DM. Dectin-1 mediates macrophage recognition of Candida albicans yeast but not filaments. EMBO J 2005 Mar 23;24(6):1277-1286.

(90) Bain JM, Louw J, Lewis LE, Okai B, Walls CA, Ballou ER, et al. Candida albicans hypha formation and mannan masking of beta-glucan inhibit macrophage phagosome maturation. MBio 2014 Dec 2;5(6):e01874-14.

(91) Hopke A, Brown AJP, Hall RA, Wheeler RT. Dynamic Fungal Cell Wall Architecture in Stress Adaptation and Immune Evasion. Trends Microbiol 2018 Apr;26(4):284-295.

(92) Barelle CJ, Priest CL, Maccallum DM, Gow NA, Odds FC, Brown AJ. Niche-specific regulation of central metabolic pathways in a fungal pathogen. Cell Microbiol 2006 Jun;8(6):961-971.

(93) Owen DH, Katz DF. A vaginal fluid simulant. Contraception 1999 Feb;59(2):91-95.

(94) Louis P, Scott KP, Duncan SH, Flint HJ. Understanding the effects of diet on bacterial metabolism in the large intestine. J Appl Microbiol 2007 May;102(5):1197-1208.

(95) Ene IV, Heilmann CJ, Sorgo AG, Walker LA, de Koster CG, Munro CA, et al. Carbon source-induced reprogramming of the cell wall proteome and secretome modulates the adherence and drug resistance of the fungal pathogen Candida albicans. Proteomics 2012 Nov;12(21):3164-3179.

(96) Weinberg ED. Nutritional immunity. Host's attempt to withold iron from microbial invaders. JAMA 1975 Jan 6;231(1):39-41.

(97) Hood MI, Skaar EP. Nutritional immunity: transition metals at the pathogen-host interface. Nat Rev Microbiol 2012 Jul 16;10(8):525-537.

(98) Potrykus J, Stead D, Maccallum DM, Urgast DS, Raab A, van Rooijen N, et al. Fungal iron availability during deep seated candidiasis is defined by a complex interplay involving systemic and local events. PLoS Pathog 2013;9(10):e1003676. 
(99) Ramanan N, Wang Y. A high-affinity iron permease essential for Candida albicans virulence. Science 2000 May 12;288(5468):1062-1064.

(100) Citiulo F, Jacobsen ID, Miramon P, Schild L, Brunke S, Zipfel P, et al. Candida albicans scavenges host zinc via Pra1 during endothelial invasion. PLoS Pathog 2012;8(6):e1002777.

(101) Lan CY, Rodarte G, Murillo LA, Jones T, Davis RW, Dungan J, et al. Regulatory networks affected by iron availability in Candida albicans. Mol Microbiol 2004 Sep;53(5):1451-1469.

(102) Malavia D, Lehtovirta-Morley LE, Alamir O, Weiss E, Gow NAR, Hube B, et al. Zinc Limitation Induces a Hyper-Adherent Goliath Phenotype in Candida albicans. Front Microbiol 2017 Nov 14;8:2238.

(103) Kjellerup L, Winther AL, Wilson D, Fuglsang AT. Cyclic AMP Pathway Activation and Extracellular Zinc Induce Rapid Intracellular Zinc Mobilization in Candida albicans. Front Microbiol 2018 Mar 21;9:502.

(104) O'Hanlon DE, Moench TR, Cone RA. Vaginal pH and microbicidal lactic acid when lactobacilli dominate the microbiota. PLoS One 2013 Nov 6;8(11):e80074.

(105) Evans DF, Pye G, Bramley R, Clark AG, Dyson TJ, Hardcastle JD. Measurement of gastrointestinal $\mathrm{pH}$ profiles in normal ambulant human subjects. Gut 1988 Aug;29(8):1035-1041.

(106) Fallingborg J. Intraluminal pH of the human gastrointestinal tract. Dan Med Bull 1999 Jun;46(3):183-196.

(107) Koziolek M, Schneider F, Grimm M, Modebeta C, Seekamp A, Roustom T, et al. Intragastric $\mathrm{pH}$ and pressure profiles after intake of the high-caloric, high-fat meal as used for food effect studies. J Control Release 2015 Dec 28;220(Pt A):71-78.

(108) Sherrington SL, Sorsby E, Mahtey N, Kumwenda P, Lenardon MD, Brown I, et al. Adaptation of Candida albicans to environmental $\mathrm{pH}$ induces cell wall remodelling and enhances innate immune recognition. PLoS Pathog 2017 May 22;13(5):e1006403.

(109) Saporito-Irwin SM, Birse CE, Sypherd PS, Fonzi WA. PHR1, a pH-regulated gene of Candida albicans, is required for morphogenesis. Mol Cell Biol 1995 Feb;15(2):601613.

(110) Hoyer LL, Payne TL, Bell M, Myers AM, Scherer S. Candida albicans ALS3 and insights into the nature of the ALS gene family. Curr Genet 1998 Jun;33(6):451-459.

(111) Bensen ES, Martin SJ, Li M, Berman J, Davis DA. Transcriptional profiling in Candida albicans reveals new adaptive responses to extracellular $\mathrm{pH}$ and functions for Rim101p. Mol Microbiol 2004 Dec;54(5):1335-1351.

(112) Moyes DL, Wilson D, Richardson JP, Mogavero S, Tang SX, Wernecke J, et al. Candidalysin is a fungal peptide toxin critical for mucosal infection. Nature $2016 \mathrm{Apr}$ 7;532(7597):64-68.

(113) Savage DC. Microbial ecology of the gastrointestinal tract. Annu Rev Microbiol 1977;31:107-133.

(114) Grahl N, Shepardson KM, Chung D, Cramer RA. Hypoxia and fungal pathogenesis: to air or not to air? Eukaryot Cell 2012 May;11(5):560-570. 
(115) Lopes JP, Stylianou M, Backman E, Holmberg S, Jass J, Claesson R, et al. Evasion of Immune Surveillance in Low Oxygen Environments Enhances Candida albicans Virulence. MBio 2018 Nov 6;9(6):10.1128/mBio.02120-18.

(116) Martinez-Lopez R, Park H, Myers CL, Gil C, Filler SG. Candida albicans Ecm33p is important for normal cell wall architecture and interactions with host cells. Eukaryot Cell 2006 Jan;5(1):140-147.

(117) Setiadi ER, Doedt T, Cottier F, Noffz C, Ernst JF. Transcriptional response of Candida albicans to hypoxia: linkage of oxygen sensing and Efg1p-regulatory networks. J Mol Biol 2006 Aug 18;361(3):399-411.

(118) Heilmann CJ, Sorgo AG, Mohammadi S, Sosinska GJ, de Koster CG, Brul S, et al. Surface stress induces a conserved cell wall stress response in the pathogenic fungus Candida albicans. Eukaryot Cell 2013 Feb;12(2):254-264.

(119) Okawa Y, Goto K. Antigenicity of cell wall mannans of Candida albicans and Candida stellatoidea cultured at high temperatures in BACTEC medium. Biol Pharm Bull 2006 Aug;29(8):1723-1727.

(120) Leach MD, Budge S, Walker L, Munro C, Cowen LE, Brown AJ. Hsp90 orchestrates transcriptional regulation by Hsf1 and cell wall remodelling by MAPK signalling during thermal adaptation in a pathogenic yeast. PLoS Pathog 2012 Dec;8(12):e1003069.

(121) Crowe JD, Sievwright IK, Auld GC, Moore NR, Gow NA, Booth NA. Candida albicans binds human plasminogen: identification of eight plasminogen-binding proteins. Mol Microbiol 2003 Mar;47(6):1637-1651.

(122) Frohner IE, Bourgeois C, Yatsyk K, Majer O, Kuchler K. Candida albicans cell surface superoxide dismutases degrade host-derived reactive oxygen species to escape innate immune surveillance. Mol Microbiol 2009 Jan;71(1):240-252.

(123) Urban C, Xiong X, Sohn K, Schroppel K, Brunner H, Rupp S. The moonlighting protein Tsa1p is implicated in oxidative stress response and in cell wall biogenesis in Candida albicans. Mol Microbiol 2005 Sep;57(5):1318-1341.

(124) Enjalbert B, Smith DA, Cornell MJ, Alam I, Nicholls S, Brown AJ, et al. Role of the Hog1 stress-activated protein kinase in the global transcriptional response to stress in the fungal pathogen Candida albicans. Mol Biol Cell 2006 Feb;17(2):1018-1032.

(125) Koyama T, Makita M, Shibata N, Okawa Y. Influence of oxidative and osmotic stresses on the structure of the cell wall mannan of Candida albicans serotype A. Carbohydr Res 2009 Nov 2;344(16):2195-2200.

(126) San Jose C, Monge RA, Perez-Diaz R, Pla J, Nombela C. The mitogen-activated protein kinase homolog HOG1 gene controls glycerol accumulation in the pathogenic fungus Candida albicans. J Bacteriol 1996 Oct;178(19):5850-5852.

(127) Smith DA, Nicholls S, Morgan BA, Brown AJ, Quinn J. A conserved stress-activated protein kinase regulates a core stress response in the human pathogen Candida albicans. Mol Biol Cell 2004 Sep;15(9):4179-4190.

(128) Herrero-de-Dios C, Alonso-Monge R, Pla J. The lack of upstream elements of the Cek1 and Hog1 mediated pathways leads to a synthetic lethal phenotype upon osmotic stress in Candida albicans. Fungal Genet Biol 2014 Aug;69:31-42. 
(129) Lindsay AK, Deveau A, Piispanen AE, Hogan DA. Farnesol and cyclic AMP signaling effects on the hypha-to-yeast transition in Candida albicans. Eukaryot Cell 2012 Oct;11(10):1219-1225.

(130) Lu Y, Su C, Unoje O, Liu H. Quorum sensing controls hyphal initiation in Candida albicans through Ubr1-mediated protein degradation. Proc Natl Acad Sci U S A 2014 Feb 4;111(5):1975-1980.

(131) Murad AM, Leng P, Straffon M, Wishart J, Macaskill S, MacCallum D, et al. NRG1 represses yeast-hypha morphogenesis and hypha-specific gene expression in Candida albicans. EMBO J 2001 Sep 3;20(17):4742-4752.

(132) Netea MG, Brown GD, Kullberg BJ, Gow NA. An integrated model of the recognition of Candida albicans by the innate immune system. Nat Rev Microbiol 2008 Jan;6(1):6778.

(133) Brown GD, Gordon S. Immune recognition. A new receptor for beta-glucans. Nature 2001 Sep 6;413(6851):36-37.

(134) Dambuza IM, Brown GD. C-type lectins in immunity: recent developments. Curr Opin Immunol 2015 Feb;32:21-27.

(135) Brown GD, Netea MG, SpringerLink. Immunology of fungal infections. 2007.

(136) Netea MG, Joosten LA, van der Meer JW, Kullberg BJ, van de Veerdonk FL. Immune defence against Candida fungal infections. Nat Rev Immunol 2015 Oct;15(10):630642.

(137) Lionakis MS, Levitz SM. Host Control of Fungal Infections: Lessons from Basic Studies and Human Cohorts. Annu Rev Immunol 2018 Apr 26;36:157-191.

(138) Wagener J, Malireddi RK, Lenardon MD, Koberle M, Vautier S, MacCallum DM, et al. Fungal chitin dampens inflammation through IL-10 induction mediated by NOD2 and TLR9 activation. PLoS Pathog 2014 Apr 10;10(4):e1004050.

(139) Wagener J, MacCallum DM, Brown GD, Gow NA. Candida albicans Chitin Increases Arginase-1 Activity in Human Macrophages, with an Impact on Macrophage Antimicrobial Functions. MBio 2017 Jan 24;8(1):10.1128/mBio.01820-16.

(140) Wheeler RT, Fink GR. A drug-sensitive genetic network masks fungi from the immune system. PLoS Pathog 2006 Apr;2(4):e35.

(141) Goodridge HS, Reyes CN, Becker CA, Katsumoto TR, Ma J, Wolf AJ, et al. Activation of the innate immune receptor Dectin-1 upon formation of a 'phagocytic synapse'. Nature 2011 Apr 28;472(7344):471-475.

(142) Mansour MK, Tam JM, Khan NS, Seward M, Davids PJ, Puranam S, et al. Dectin-1 activation controls maturation of beta-1,3-glucan-containing phagosomes. J Biol Chem 2013 May 31;288(22):16043-16054.

(143) Taylor PR, Tsoni SV, Willment JA, Dennehy KM, Rosas M, Findon H, et al. Dectin-1 is required for beta-glucan recognition and control of fungal infection. Nat Immunol 2007 Jan;8(1):31-38.

(144) Ferwerda B, Ferwerda G, Plantinga TS, Willment JA, van Spriel AB, Venselaar H, et al. Human dectin-1 deficiency and mucocutaneous fungal infections. N Engl J Med 2009 Oct 29;361(18):1760-1767. 
(145) Sem X, Le GT, Tan AS, Tso G, Yurieva M, Liao WW, et al. beta-glucan Exposure on the Fungal Cell Wall Tightly Correlates with Competitive Fitness of Candida Species in the Mouse Gastrointestinal Tract. Front Cell Infect Microbiol 2016 Dec 22;6:186.

(146) Saeed S, Quintin J, Kerstens HH, Rao NA, Aghajanirefah A, Matarese F, et al. Epigenetic programming of monocyte-to-macrophage differentiation and trained innate immunity. Science 2014 Sep 26;345(6204):1251086.

(147) Drummond RA, Dambuza IM, Vautier S, Taylor JA, Reid DM, Bain CC, et al. CD4(+) T-cell survival in the $\mathrm{GI}$ tract requires dectin-1 during fungal infection. Mucosal Immunol 2016 Mar;9(2):492-502.

(148) Xia Y, Vetvicka V, Yan J, Hanikyrova M, Mayadas T, Ross GD. The beta-glucanbinding lectin site of mouse CR3 (CD11b/CD18) and its function in generating a primed state of the receptor that mediates cytotoxic activation in response to iC3bopsonized target cells. J Immunol 1999 Feb 15;162(4):2281-2290.

(149) Thornton BP, Vetvicka V, Pitman M, Goldman RC, Ross GD. Analysis of the sugar specificity and molecular location of the beta-glucan-binding lectin site of complement receptor type 3 (CD11b/CD18). J Immunol 1996 Feb 1;156(3):1235-1246.

(150) Maxson ME, Naj X, O'Meara TR, Plumb JD, Cowen LE, Grinstein S. Integrin-based diffusion barrier separates membrane domains enabling the formation of microbiostatic frustrated phagosomes. Elife 2018 Mar 19;7:10.7554/eLife.34798.

(151) Jimenez-Lucho V, Ginsburg V, Krivan HC. Cryptococcus neoformans, Candida albicans, and other fungi bind specifically to the glycosphingolipid lactosylceramide (Gal beta 1-4Glc beta 1-1Cer), a possible adhesion receptor for yeasts. Infect Immun 1990 Jul;58(7):2085-2090.

(152) Means TK, Mylonakis E, Tampakakis E, Colvin RA, Seung E, Puckett L, et al. Evolutionarily conserved recognition and innate immunity to fungal pathogens by the scavenger receptors SCARF1 and CD36. J Exp Med 2009 Mar 16;206(3):637-653.

(153) Guo Y, Chang Q, Cheng L, Xiong S, Jia X, Lin X, et al. C-Type Lectin Receptor CD23 Is Required for Host Defense against Candida albicans and Aspergillus fumigatus Infection. J Immunol 2018 Oct 15;201(8):2427-2440.

(154) van de Veerdonk FL, Marijnissen RJ, Kullberg BJ, Koenen HJ, Cheng SC, Joosten I, et al. The macrophage mannose receptor induces IL-17 in response to Candida albicans. Cell Host Microbe 2009 Apr 23;5(4):329-340.

(155) Te Riet J, Joosten B, Reinieren-Beeren I, Figdor CG, Cambi A. N-glycan mediated adhesion strengthening during pathogen-receptor binding revealed by cell-cell force spectroscopy. Sci Rep 2017 Jul 27;7(1):6713-017-07220-w.

(156) McGreal EP, Rosas M, Brown GD, Zamze S, Wong SY, Gordon S, et al. The carbohydrate-recognition domain of Dectin-2 is a C-type lectin with specificity for high mannose. Glycobiology 2006 May;16(5):422-430.

(157) Saijo S, Ikeda S, Yamabe K, Kakuta S, Ishigame H, Akitsu A, et al. Dectin-2 recognition of alpha-mannans and induction of Th17 cell differentiation is essential for host defense against Candida albicans. Immunity 2010 May 28;32(5):681-691.

(158) Zhu LL, Zhao XQ, Jiang C, You Y, Chen XP, Jiang YY, et al. C-type lectin receptors Dectin-3 and Dectin-2 form a heterodimeric pattern-recognition receptor for host defense against fungal infection. Immunity 2013 Aug 22;39(2):324-334. 
(159) Wells CA, Salvage-Jones JA, Li X, Hitchens K, Butcher S, Murray RZ, et al. The macrophage-inducible C-type lectin, mincle, is an essential component of the innate immune response to Candida albicans. J Immunol 2008 Jun 1;180(11):7404-7413.

(160) Vijayan D, Radford KJ, Beckhouse AG, Ashman RB, Wells CA. Mincle polarizes human monocyte and neutrophil responses to Candida albicans. Immunol Cell Biol 2012 Oct;90(9):889-895.

(161) Held K, Thiel S, Loos M, Petry F. Increased susceptibility of complement factor B/C2 double knockout mice and mannan-binding lectin knockout mice to systemic infection with Candida albicans. Mol Immunol 2008 Sep;45(15):3934-3941.

(162) Choteau L, Parny M, Francois N, Bertin B, Fumery M, Dubuquoy L, et al. Role of mannose-binding lectin in intestinal homeostasis and fungal elimination. Mucosal Immunol 2016 May;9(3):767-776.

(163) Dong R, Zhang M, Hu Q, Zheng S, Soh A, Zheng Y, et al. Galectin-3 as a novel biomarker for disease diagnosis and a target for therapy (Review). Int J Mol Med 2018 Feb;41(2):599-614.

(164) Kohatsu L, Hsu DK, Jegalian AG, Liu FT, Baum LG. Galectin-3 induces death of Candida species expressing specific beta-1,2-linked mannans. J Immunol 2006 Oct 1;177(7):4718-4726.

(165) Roman E, Correia I, Salazin A, Fradin C, Jouault T, Poulain D, et al. The Cek1mediated MAP kinase pathway regulates exposure of alpha1,2 and beta1,2mannosides in the cell wall of Candida albicans modulating immune recognition. Virulence 2016 Jul 3;7(5):558-577.

(166) de Jong MA, Vriend LE, Theelen B, Taylor ME, Fluitsma D, Boekhout T, et al. C-type lectin Langerin is a beta-glucan receptor on human Langerhans cells that recognizes opportunistic and pathogenic fungi. Mol Immunol 2010 Mar;47(6):1216-1225.

(167) De Jesus M, Rodriguez AE, Yagita H, Ostroff GR, Mantis NJ. Sampling of Candida albicans and Candida tropicalis by Langerin-positive dendritic cells in mouse Peyer's patches. Immunol Lett 2015 Nov; 168(1):64-72.

(168) Lemaitre B, Nicolas E, Michaut L, Reichhart JM, Hoffmann JA. The dorsoventral regulatory gene cassette spatzle/Toll/cactus controls the potent antifungal response in Drosophila adults. Cell 1996 Sep 20;86(6):973-983.

(169) Netea MG, Van Der Graaf CA, Vonk AG, Verschueren I, Van Der Meer JW, Kullberg BJ. The role of toll-like receptor (TLR) 2 and TLR4 in the host defense against disseminated candidiasis. J Infect Dis 2002 May 15;185(10):1483-1489.

(170) Tada H, Nemoto E, Shimauchi H, Watanabe T, Mikami T, Matsumoto T, et al. Saccharomyces cerevisiae- and Candida albicans-derived mannan induced production of tumor necrosis factor alpha by human monocytes in a CD14- and Toll-like receptor 4-dependent manner. Microbiol Immunol 2002;46(7):503-512.

(171) Jouault T, Ibata-Ombetta S, Takeuchi O, Trinel PA, Sacchetti P, Lefebvre P, et al. Candida albicans phospholipomannan is sensed through toll-like receptors. J Infect Dis 2003 Jul 1;188(1):165-172.

(172) Netea MG, Gow NA, Munro CA, Bates S, Collins C, Ferwerda G, et al. Immune sensing of Candida albicans requires cooperative recognition of mannans and glucans by lectin and Toll-like receptors. J Clin Invest 2006 Jun;116(6):1642-1650. 
(173) Brown GD, Herre J, Williams DL, Willment JA, Marshall AS, Gordon S. Dectin-1 mediates the biological effects of beta-glucans. J Exp Med 2003 May 5;197(9):11191124

(174) Gantner BN, Simmons RM, Canavera SJ, Akira S, Underhill DM. Collaborative induction of inflammatory responses by dectin-1 and Toll-like receptor 2. J Exp Med 2003 May 5;197(9):1107-1117.

(175) Taylor PR, Brown GD, Herre J, Williams DL, Willment JA, Gordon S. The role of SIGNR1 and the beta-glucan receptor (dectin-1) in the nonopsonic recognition of yeast by specific macrophages. J Immunol 2004 Jan 15;172(2):1157-1162.

(176) Huang JH, Lin CY, Wu SY, Chen WY, Chu CL, Brown GD, et al. CR3 and Dectin-1 Collaborate in Macrophage Cytokine Response through Association on Lipid Rafts and Activation of Syk-JNK-AP-1 Pathway. PLoS Pathog 2015 Jul 1;11(7):e1004985.

(177) Wheeler RT, Kombe D, Agarwala SD, Fink GR. Dynamic, morphotype-specific Candida albicans beta-glucan exposure during infection and drug treatment. PLoS Pathog 2008 Dec;4(12):e1000227.

(178) Hopke A, Nicke N, Hidu EE, Degani G, Popolo L, Wheeler RT. Neutrophil Attack Triggers Extracellular Trap-Dependent Candida Cell Wall Remodeling and Altered Immune Recognition. PLoS Pathog 2016 May 25;12(5):e1005644.

(179) Ballou ER, Avelar GM, Childers DS, Mackie J, Bain JM, Wagener J, et al. Lactate signalling regulates fungal beta-glucan masking and immune evasion. Nat Microbiol 2016 Dec 12;2:16238.

(180) Hall RA, Noverr MC. Fungal interactions with the human host: exploring the spectrum of symbiosis. Curr Opin Microbiol 2017 Dec;40:58-64.

(181) Cuskin F, Lowe EC, Temple MJ, Zhu Y, Cameron E, Pudlo NA, et al. Human gut Bacteroidetes can utilize yeast mannan through a selfish mechanism. Nature 2015 Jan 8;517(7533):165-169.

(182) Luther K, Torosantucci A, Brakhage AA, Heesemann J, Ebel F. Phagocytosis of Aspergillus fumigatus conidia by murine macrophages involves recognition by the dectin-1 beta-glucan receptor and Toll-like receptor 2. Cell Microbiol 2007 Feb;9(2):368-381.

(183) Heinekamp T, Schmidt H, Lapp K, Pahtz V, Shopova I, Koster-Eiserfunke N, et al. Interference of Aspergillus fumigatus with the immune response. Semin Immunopathol 2015 Mar;37(2):141-152.

(184) Stappers MHT, Clark AE, Aimanianda V, Bidula S, Reid DM, Asamaphan P, et al. Recognition of DHN-melanin by a C-type lectin receptor is required for immunity to Aspergillus. Nature 2018 Mar 15;555(7696):382-386.

(185) Hohl TM, Van Epps HL, Rivera A, Morgan LA, Chen PL, Feldmesser M, et al. Aspergillus fumigatus triggers inflammatory responses by stage-specific beta-glucan display. PLoS Pathog 2005 Nov;1(3):e30.

(186) Aimanianda V, Bayry J, Bozza S, Kniemeyer O, Perruccio K, Elluru SR, et al. Surface hydrophobin prevents immune recognition of airborne fungal spores. Nature 2009 Aug 27;460(7259):1117-1121.

(187) Carrion Sde J, Leal SM,Jr, Ghannoum MA, Aimanianda V, Latge JP, Pearlman E. The RodA hydrophobin on Aspergillus fumigatus spores masks dectin-1- and dectin-2- 
dependent responses and enhances fungal survival in vivo. J Immunol 2013 Sep 1;191(5):2581-2588.

(188) Langfelder K, Jahn B, Gehringer H, Schmidt A, Wanner G, Brakhage AA. Identification of a polyketide synthase gene ( $\mathrm{pksP}$ ) of Aspergillus fumigatus involved in conidial pigment biosynthesis and virulence. Med Microbiol Immunol 1998 Oct;187(2):79-89.

(189) Thywissen A, Heinekamp T, Dahse HM, Schmaler-Ripcke J, Nietzsche S, Zipfel PF, et al. Conidial Dihydroxynaphthalene Melanin of the Human Pathogenic Fungus Aspergillus fumigatus Interferes with the Host Endocytosis Pathway. Front Microbiol 2011 May 3;2:96.

(190) Gravelat FN, Beauvais A, Liu H, Lee MJ, Snarr BD, Chen D, et al. Aspergillus galactosaminogalactan mediates adherence to host constituents and conceals hyphal beta-glucan from the immune system. PLoS Pathog 2013;9(8):e1003575.

(191) Voelz K, May RC. Cryptococcal interactions with the host immune system. Eukaryot Cell 2010 Jun;9(6):835-846.

(192) Heung LJ. Innate Immune Responses to Cryptococcus. J Fungi (Basel) 2017 Sep;3(3):10.3390/jof3030035. Epub 2017 Jul 2.

(193) Shoham S, Huang C, Chen JM, Golenbock DT, Levitz SM. Toll-like receptor 4 mediates intracellular signaling without TNF-alpha release in response to Cryptococcus neoformans polysaccharide capsule. J Immunol $2001 \mathrm{Apr}$ 1;166(7):4620-4626.

(194) Yauch LE, Mansour MK, Shoham S, Rottman JB, Levitz SM. Involvement of CD14, toll-like receptors 2 and 4, and MyD88 in the host response to the fungal pathogen Cryptococcus neoformans in vivo. Infect Immun 2004 Sep;72(9):5373-5382.

(195) Geunes-Boyer S, Oliver TN, Janbon G, Lodge JK, Heitman J, Perfect JR, et al. Surfactant protein $D$ increases phagocytosis of hypocapsular Cryptococcus neoformans by murine macrophages and enhances fungal survival. Infect Immun 2009 Jul;77(7):2783-2794.

(196) Mansour MK, Schlesinger LS, Levitz SM. Optimal T cell responses to Cryptococcus neoformans mannoprotein are dependent on recognition of conjugated carbohydrates by mannose receptors. J Immunol 2002 Mar 15;168(6):2872-2879.

(197) Dan JM, Kelly RM, Lee CK, Levitz SM. Role of the mannose receptor in a murine model of Cryptococcus neoformans infection. Infect Immun 2008 Jun;76(6):2362-2367.

(198) Nakamura K, Kinjo T, Saijo S, Miyazato A, Adachi Y, Ohno N, et al. Dectin-1 is not required for the host defense to Cryptococcus neoformans. Microbiol Immunol 2007;51(11):1115-1119.

(199) Nakamura Y, Sato K, Yamamoto H, Matsumura K, Matsumoto I, Nomura T, et al. Dectin-2 deficiency promotes Th2 response and mucin production in the lungs after pulmonary infection with Cryptococcus neoformans. Infect Immun 2015 Feb;83(2):671681.

(200) Campuzano A, Castro-Lopez N, Wozniak KL, Leopold Wager CM, Wormley FL,Jr. Dectin-3 Is Not Required for Protection against Cryptococcus neoformans Infection. PLoS One 2017 Jan 20;12(1):e0169347. 
(201) Rappleye CA, Eissenberg LG, Goldman WE. Histoplasma capsulatum alpha-(1,3)glucan blocks innate immune recognition by the beta-glucan receptor. Proc Natl Acad Sci U S A 2007 Jan 23;104(4):1366-1370.

(202) San-Blas G, San-Blas F, Serrano LE. Host-parasite relationships in the yeastlike form of Paracoccidioides brasiliensis strain IVIC Pb9. Infect Immun 1977 Feb;15(2):343346.

(203) Hogan LH, Klein BS. Altered expression of surface alpha-1,3-glucan in genetically related strains of Blastomyces dermatitidis that differ in virulence. Infect Immun 1994 Aug;62(8):3543-3546.

(204) Edwards JA, Alore EA, Rappleye CA. The yeast-phase virulence requirement for alpha-glucan synthase differs among Histoplasma capsulatum chemotypes. Eukaryot Cell 2011 Jan;10(1):87-97.

(205) Rappleye CA, Engle JT, Goldman WE. RNA interference in Histoplasma capsulatum demonstrates a role for alpha-(1,3)-glucan in virulence. Mol Microbiol 2004 Jul;53(1):153-165.

(206) Garfoot AL, Rappleye CA. Histoplasma capsulatum surmounts obstacles to intracellular pathogenesis. FEBS J 2016 Feb;283(4):619-633.

(207) Pericolini E, Perito S, Castagnoli A, Gabrielli E, Mencacci A, Blasi E, et al. Epitope unmasking in vulvovaginal candidiasis is associated with hyphal growth and neutrophilic infiltration. PLoS One 2018 Jul 31;13(7):e0201436.

(208) Garfoot AL, Shen Q, Wuthrich M, Klein BS, Rappleye CA. The Eng1 beta-Glucanase Enhances Histoplasma Virulence by Reducing beta-Glucan Exposure. MBio 2016 Apr 19;7(2):e01388-15.

(209) Delgado-Silva Y, Vaz C, Carvalho-Pereira J, Carneiro C, Nogueira E, Correia A, et al. Participation of Candida albicans transcription factor RLM1 in cell wall biogenesis and virulence. PLoS One 2014 Jan 23;9(1):e86270.

(210) Cheetham J, Smith DA, da Silva Dantas A, Doris KS, Patterson MJ, Bruce CR, et al. A single MAPKKK regulates the Hog1 MAPK pathway in the pathogenic fungus Candida albicans. Mol Biol Cell 2007 Nov;18(11):4603-4614.

(211) Day AM, Smith DA, Ikeh MA, Haider M, Herrero-de-Dios CM, Brown AJ, et al. Blocking two-component signalling enhances Candida albicans virulence and reveals adaptive mechanisms that counteract sustained SAPK activation. PLoS Pathog 2017 Jan 30;13(1):e1006131.

(212) Su C, Lu Y, Liu H. Reduced TOR signaling sustains hyphal development in Candida albicans by lowering Hog1 basal activity. Mol Biol Cell 2013 Feb;24(3):385-397.

(213) Monge RA, Roman E, Nombela C, Pla J. The MAP kinase signal transduction network in Candida albicans. Microbiology 2006 Apr;152(Pt 4):905-912.

(214) Leberer E, Harcus D, Broadbent ID, Clark KL, Dignard D, Ziegelbauer K, et al. Signal transduction through homologs of the Ste20p and Ste7p protein kinases can trigger hyphal formation in the pathogenic fungus Candida albicans. Proc Natl Acad Sci U S A 1996 Nov 12;93(23):13217-13222.

(215) Roman E, Cottier F, Ernst JF, Pla J. Msb2 signaling mucin controls activation of Cek1 mitogen-activated protein kinase in Candida albicans. Eukaryot Cell 2009 Aug;8(8):1235-1249. 
(216) Cantero PD, Ernst JF. Damage to the glycoshield activates PMT-directed Omannosylation via the Msb2-Cek1 pathway in Candida albicans. Mol Microbiol 2011 May;80(3):715-725.

(217) Herrero de Dios C, Roman E, Diez C, Alonso-Monge R, Pla J. The transmembrane protein Opy2 mediates activation of the Cek1 MAP kinase in Candida albicans. Fungal Genet Biol 2013 Jan;50:21-32.

(218) Noble SM, Gianetti BA, Witchley JN. Candida albicans cell-type switching and functional plasticity in the mammalian host. Nat Rev Microbiol 2017 Feb;15(2):96-108.

(219) Fanning S, Xu W, Beaurepaire C, Suhan JP, Nantel A, Mitchell AP. Functional control of the Candida albicans cell wall by catalytic protein kinase A subunit Tpk1. Mol Microbiol 2012 Oct;86(2):284-302.

(220) Lu Y, Su C, Liu H. Candida albicans hyphal initiation and elongation. Trends Microbiol 2014 Dec;22(12):707-714.

(221) Sanglard D, Ischer F, Marchetti O, Entenza J, Bille J. Calcineurin A of Candida albicans: involvement in antifungal tolerance, cell morphogenesis and virulence. Mol Microbiol 2003 May;48(4):959-976.

(222) Sato T, Ueno Y, Watanabe T, Mikami T, Matsumoto T. Role of Ca2+/calmodulin signaling pathway on morphological development of Candida albicans. Biol Pharm Bull 2004 Aug;27(8):1281-1284.

(223) Santos M, de Larrinoa IF. Functional characterization of the Candida albicans CRZ1 gene encoding a calcineurin-regulated transcription factor. Curr Genet 2005 Aug;48(2):88-100.

(224) Karababa M, Valentino E, Pardini G, Coste AT, Bille J, Sanglard D. CRZ1, a target of the calcineurin pathway in Candida albicans. Mol Microbiol 2006 Mar;59(5):1429-1451. 


\section{Figure 1}

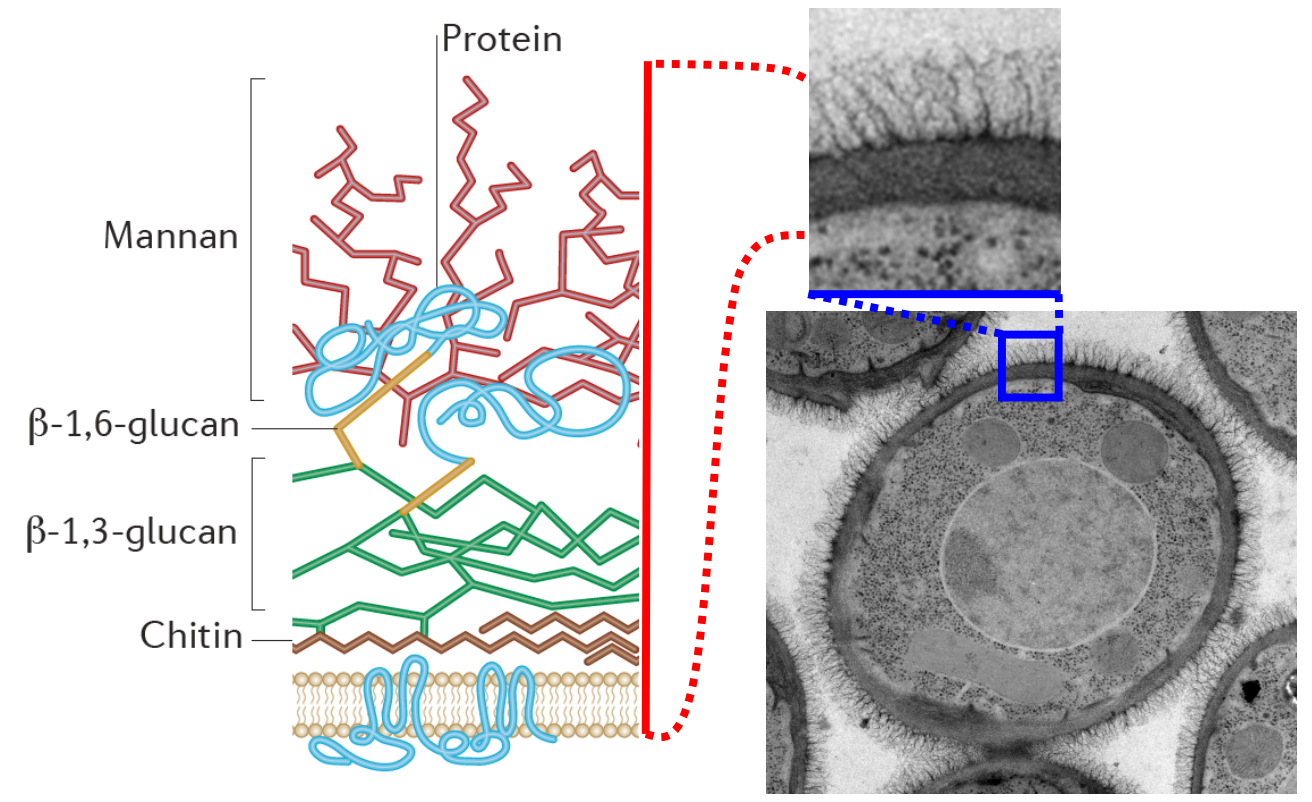




\section{Figure 2}

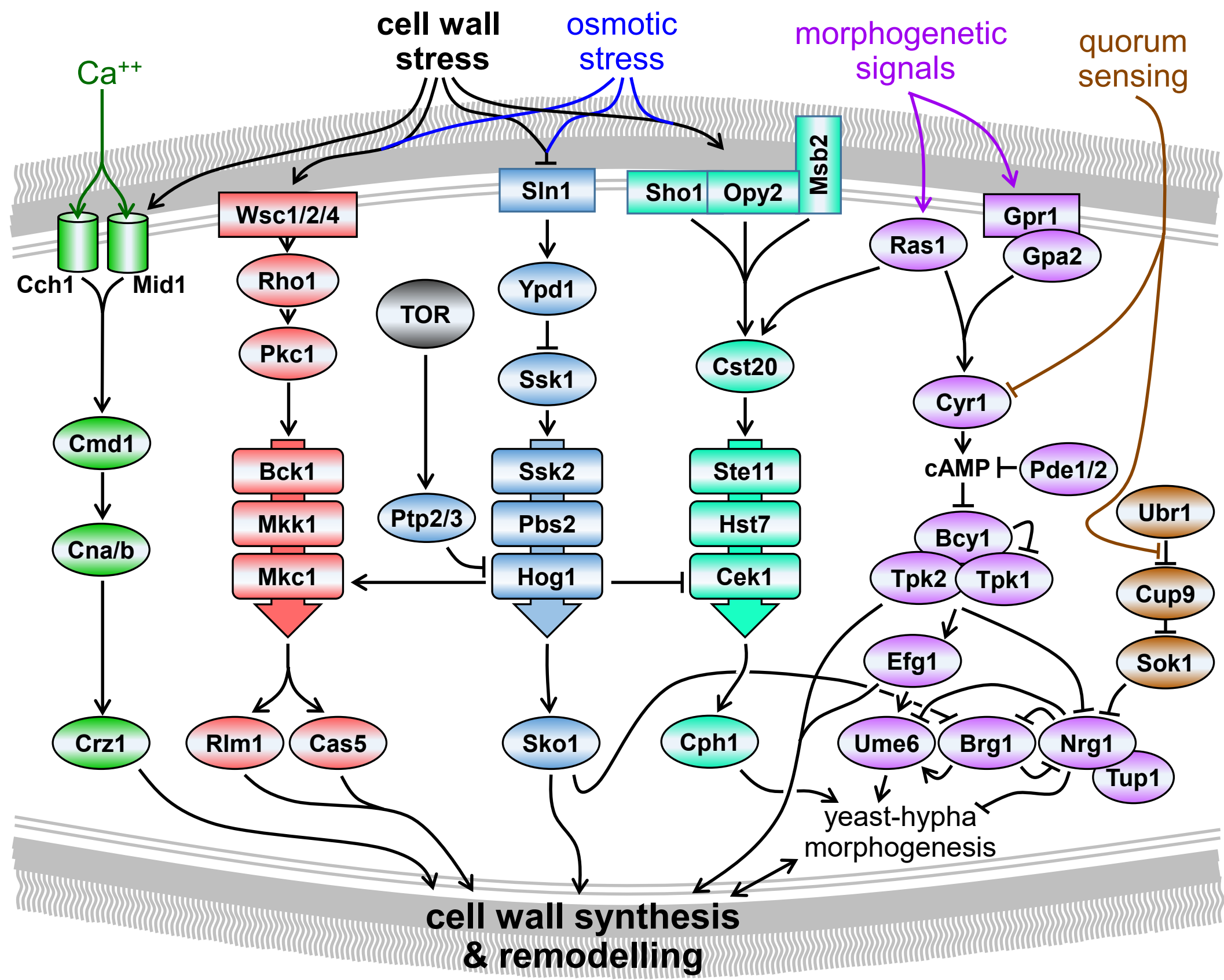




\section{Figure 3}

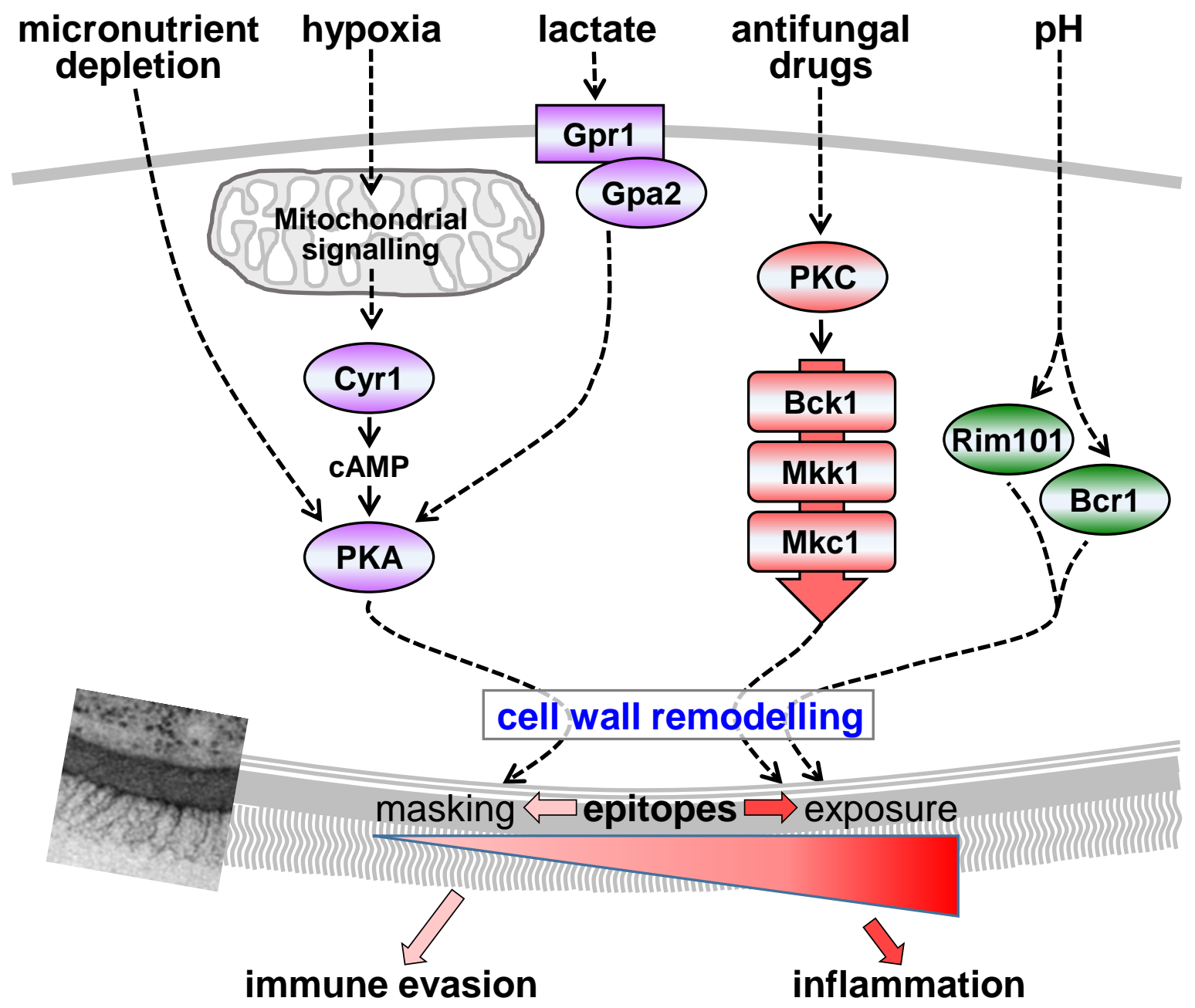


Figure 4

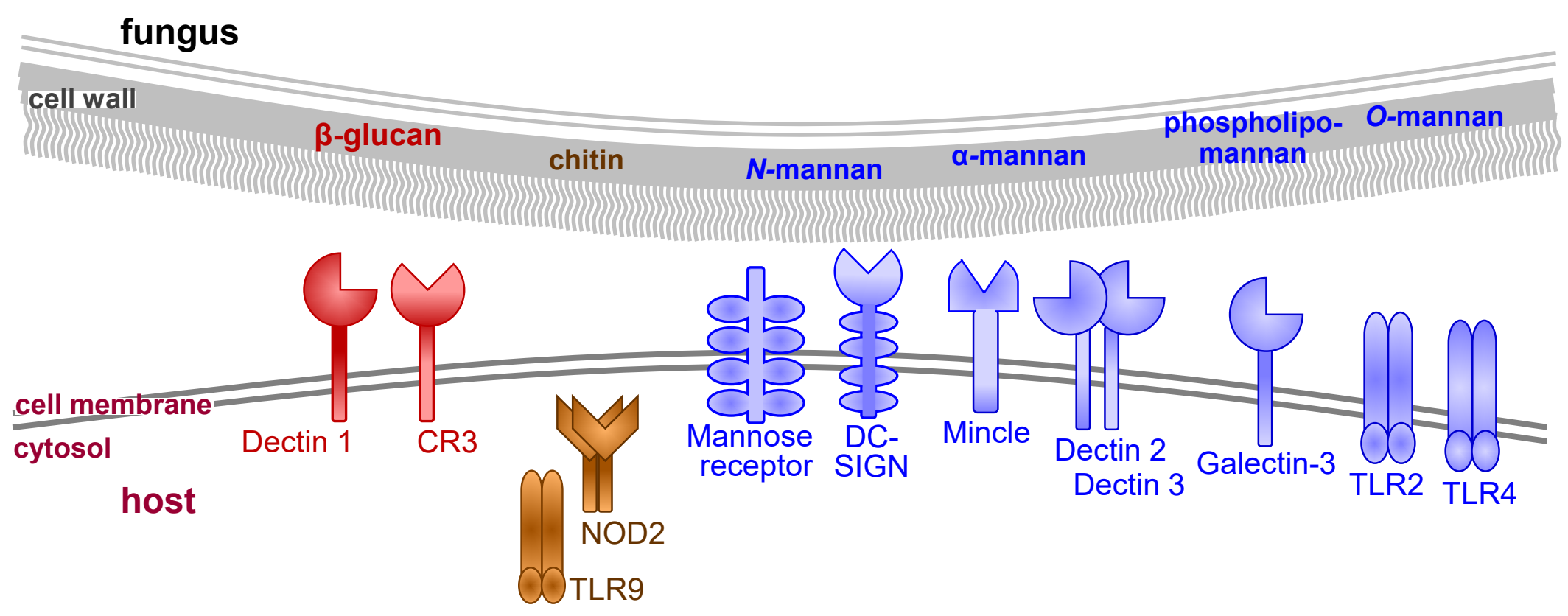

